\title{
LEVEL II SCOUR ANALYSIS FOR BRIDGE 8 (ANDOTH00010008) on TOWN HIGHWAY 1, crossing the ANDOVER BRANCH, ANDOVER , VERMONT
}

U.S. Geological Survey

Open-File Report 97-374

Prepared in cooperation with

VERMONT AGENCY OF TRANSPORTATION

and

FEDERAL HIGHWAY ADMINISTRATION 


\section{LEVEL II SCOUR ANALYSIS FOR BRIDGE 8 (ANDOTH00010008) on TOWN HIGHWAY 1, crossing the ANDOVER BRANCH, ANDOVER , VERMONT \\ By ROBERT H. FLYNN AND EMILY C. WILD}

U.S. Geological Survey

Open-File Report 97-374

Prepared in cooperation with

VERMONT AGENCY OF TRANSPORTATION

and

FEDERAL HIGHWAY ADMINISTRATION 


\title{
U.S. DEPARTMENT OF THE INTERIOR BRUCE BABBITT, Secretary
}

\author{
U.S. GEOLOGICAL SURVEY \\ Gordon P. Eaton, Director
}

For additional information write to:

District Chief

U.S. Geological Survey 361 Commerce Way

Pembroke, NH 03275-3718
Copies of this report may be purchased from:

U.S. Geological Survey

Branch of Information Services

Open-File Reports Unit

Box 25286

Denver, CO 80225-0286 


\section{CONTENTS}

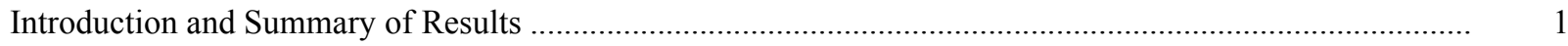

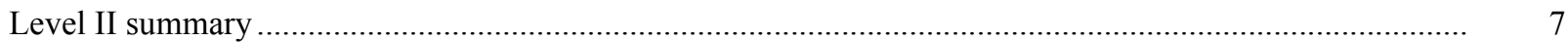

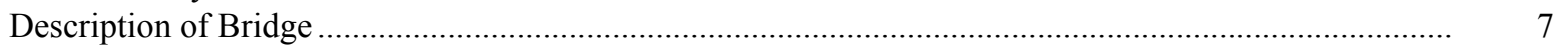

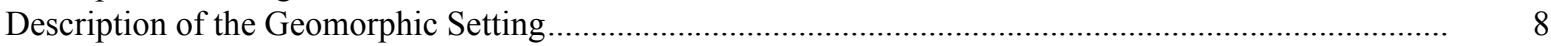

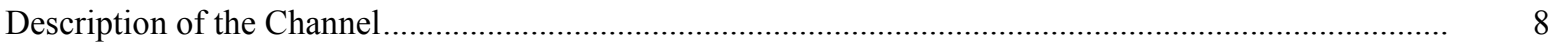

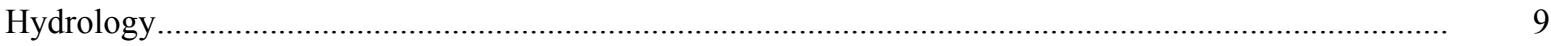

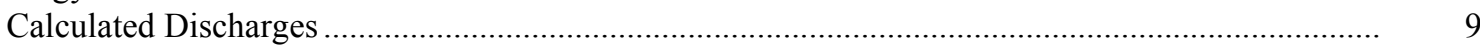

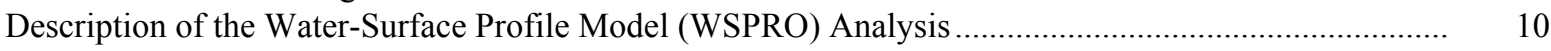

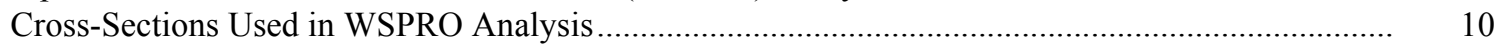

Data and Assumptions Used in WSPRO Model ...................................................................... 11

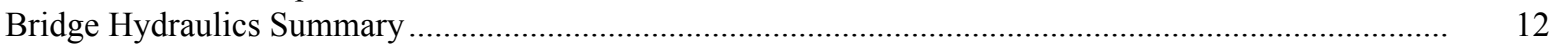

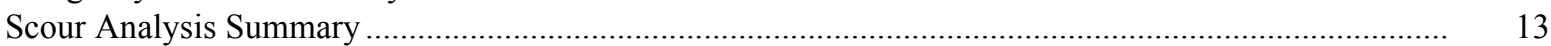

Special Conditions or Assumptions Made in Scour Analysis ...................................................... 13

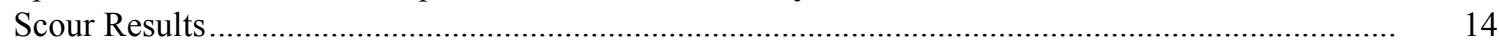

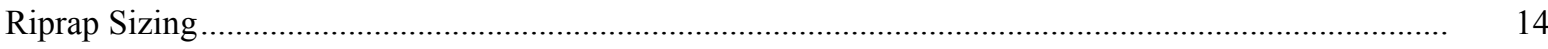

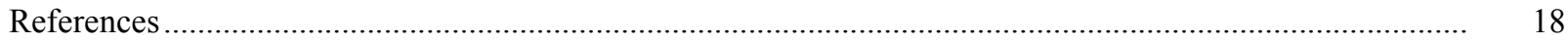

Appendixes:

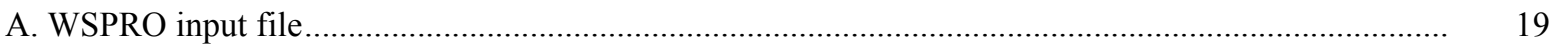

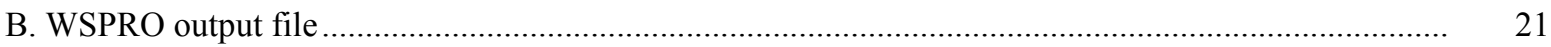

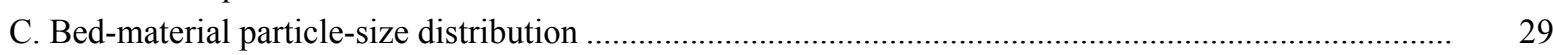

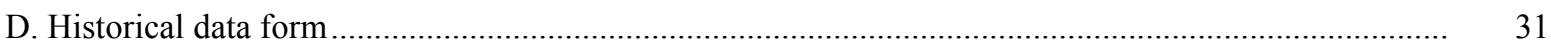

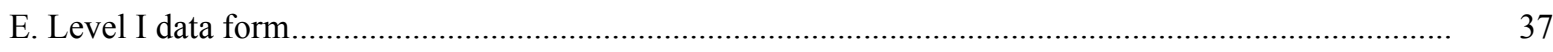

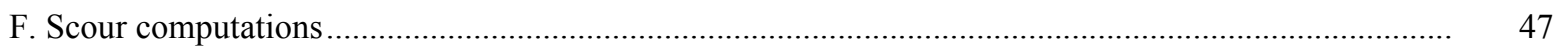

\section{FIGURES}

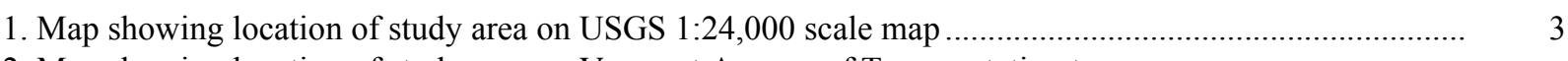

2. Map showing location of study area on Vermont Agency of Transportation town
highway map

3. Structure ANDOTH00010008 viewed from upstream (August 27, 1996) …......................................... 5

4. Downstream channel viewed from structure ANDOTH00010008 (August 27, 1996). .......................... 5

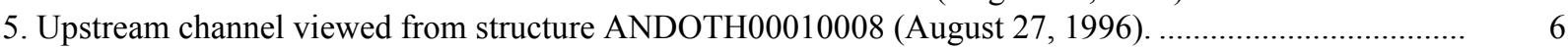

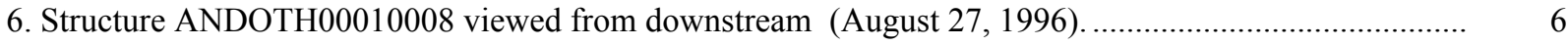

7. Water-surface profiles for the 100- and 500-year discharges at structure

ANDOTH00010008 on Town Highway 1, crossing the Andover Branch,

Andover, Vermont.

8. Scour elevations for the 100- and 500-year discharges at structure

ANDOTH00010008 on Town Highway 1, crossing the Andover Branch,

Andover, Vermont.

\section{TABLES}

1. Remaining footing/pile depth at abutments for the 100-year discharge at structure

ANDOTH00010008 on Town Highway 1, crossing the Andover Branch,

Andover, Vermont .....

2. Remaining footing/pile depth at abutments for the 500-year discharge at structure

ANDOTH00010008 on Town Highway 1, crossing the Andover Branch,

Andover, Vermont 


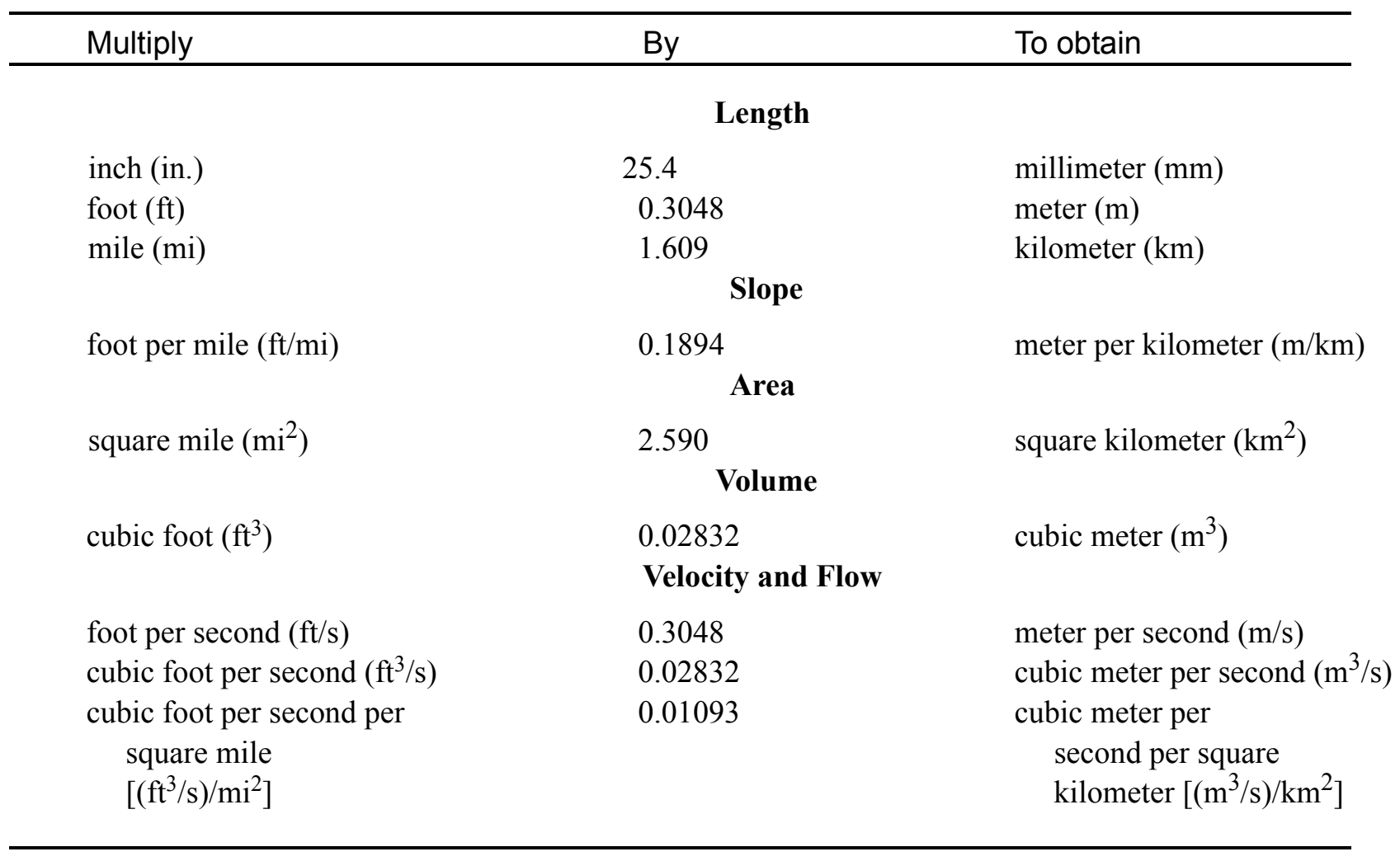

\section{OTHER ABBREVIATIONS}

$\begin{array}{lrlr}\mathrm{BF} & \text { bank full } & \text { LWW } & \text { left wingwall } \\ \mathrm{cfs} & \text { cubic feet per second } & \text { MC } & \text { main channel } \\ \mathrm{D}_{50} & \text { median diameter of bed material } & \text { RAB } & \text { right abutment } \\ \mathrm{DS} & \text { downstream } & \text { RABUT } & \text { face of right abutment } \\ \mathrm{elev} & \text { elevation } & \text { RB } & \text { right bank } \\ \mathrm{f} / \mathrm{p} & \text { flood plain } & \text { ROB } & \text { right overbank } \\ \mathrm{ft}^{2} & \text { square feet } & \text { RWW } & \text { right wingwall } \\ \mathrm{ft} / \mathrm{ft} & \text { feet per foot } & \text { TH } & \text { town highway } \\ \mathrm{JCT} & \text { junction } & \text { UB } & \text { under bridge } \\ \mathrm{LAB} & \text { left abutment } & \text { US } & \text { upstream } \\ \mathrm{LABUT} & \text { face of left abutment } & \text { USGS } & \text { United States Geological Survey } \\ \mathrm{LB} & \text { left bank } & \text { VTAOT Vermont Agency of Transportation } \\ \mathrm{LOB} & \text { left overbank } & \text { WSPRO } & \text { water-surface profile model }\end{array}$

In this report, the words "right" and "left" refer to directions that would be reported by an observer facing downstream. Sea level: In this report, "sea level" refers to the National Geodetic Vertical Datum of 1929-- a geodetic datum derived from a general adjustment of the first-order level nets of the United States and Canada, formerly called Sea Level Datum of 1929.

In the appendices, the above abbreviations may be combined. For example, USLB would represent upstream left bank. 


\title{
LEVEL II SCOUR ANALYSIS FOR BRIDGE 8 (ANDOTH00010008) ON TOWN HIGHWAY 1, CROSSING ANDOVER BRANCH, ANDOVER, VERMONT
}

\author{
By Robert H. Flynn and Emily C. Wild
}

\section{INTRODUCTION AND SUMMARY OF RESULTS}

This report provides the results of a detailed Level II analysis of scour potential at structure ANDOTH00010008 on Town Highway 1 crossing the Andover Branch, Andover, Vermont (figures 1-8). A Level II study is a basic engineering analysis of the site, including a quantitative analysis of stream stability and scour (U.S. Department of Transportation, 1993). Results of a Level I scour investigation also are included in Appendix E of this report. A Level I investigation provides a qualitative geomorphic characterization of the study site. Information on the bridge, gleaned from Vermont Agency of Transportation (VTAOT) files, was compiled prior to conducting Level I and Level II analyses and is found in Appendix D.

The site is in the Green Mountain section of the New England physiographic province in south-central Vermont. The $5.30-\mathrm{mi}^{2}$ drainage area is in a predominantly rural and forested basin. In the vicinity of the study site, the surface cover along the immediate banks, both upstream and downstream of the bridge, is grass while farther upstream and downstream, the surface cover is primarily forest.

In the study area, the Andover Branch has an incised, straight channel with a slope of approximately $0.01 \mathrm{ft} / \mathrm{ft}$, an average channel top width of $35 \mathrm{ft}$ and an average bank height of $3 \mathrm{ft}$. The channel bed material ranges from gravel to boulder with a median grain size $\left(\mathrm{D}_{50}\right)$ of $63.6 \mathrm{~mm}(0.209 \mathrm{ft})$. The geomorphic assessment at the time of the Level I and Level II site visit on August 27, 1996, indicated that the reach was stable.

The Town Highway 1 crossing of the Andover Branch is a 54-ft-long, two-lane bridge consisting of one 51-foot steel-beam span (Vermont Agency of Transportation, written communication, March 28, 1995). The bridge is supported by vertical, concrete abutments with wingwalls. The channel is skewed approximately 45 degrees to the opening while the opening-skew-to-roadway is 30 degrees. 
A scour hole $0.7 \mathrm{ft}$ deeper than the mean thalweg depth was observed approximately 52 feet downstream of the downstream face of the bridge during the Level I assessment. Scour countermeasures at the site include type- 2 stone fill (less than 36 inches diameter) along the entire base length of the left and right abutments and along the left bank from $65 \mathrm{ft}$ to $89 \mathrm{ft}$ upstream. Type-1 stone fill was found along the right bank from the bridge to $47 \mathrm{ft}$ upstream and along the left bank from $40 \mathrm{ft}$ to $65 \mathrm{ft}$ upstream. Additional details describing conditions at the site are included in the Level II Summary and Appendices D and E.

Scour depths and rock rip-rap sizes were computed using the general guidelines described in Hydraulic Engineering Circular 18 (Richardson and others, 1995). Total scour at a highway crossing is comprised of three components: 1) long-term streambed degradation; 2) contraction scour (due to accelerated flow caused by a reduction in flow area at a bridge) and; 3) local scour (caused by accelerated flow around piers and abutments). Total scour is the sum of the three components. Equations are available to compute depths for contraction and local scour and a summary of the results of these computations follows.

Contraction scour for all modelled flows ranged from 0.0 to $0.1 \mathrm{ft}$. The worst case contraction scour occurred at the 500-year discharge. Abutment scour ranged from 5.0 to $8.1 \mathrm{ft}$ along the left abutment and from 2.1 to $4.6 \mathrm{ft}$ along the right abutment. The worst-case abutment scour occurred at the 500-year discharge. Additional information on scour depths and depths to armoring are included in the section titled "Scour Results". Scouredstreambed elevations, based on the calculated scour depths, are presented in tables 1 and 2. A cross-section of the scour computed at the bridge is presented in figure 8. Scour depths were calculated assuming an infinite depth of erosive material and a homogeneous particlesize distribution.

It is generally accepted that the Froehlich equation (abutment scour) gives "excessively conservative estimates of scour depths" (Richardson and others, 1995, p. 47). Usually, computed scour depths are evaluated in combination with other information including (but not limited to) historical performance during flood events, the geomorphic stability assessment, existing scour protection measures, and the results of the hydraulic analyses. Therefore, scour depths adopted by VTAOT may differ from the computed values documented herein. 


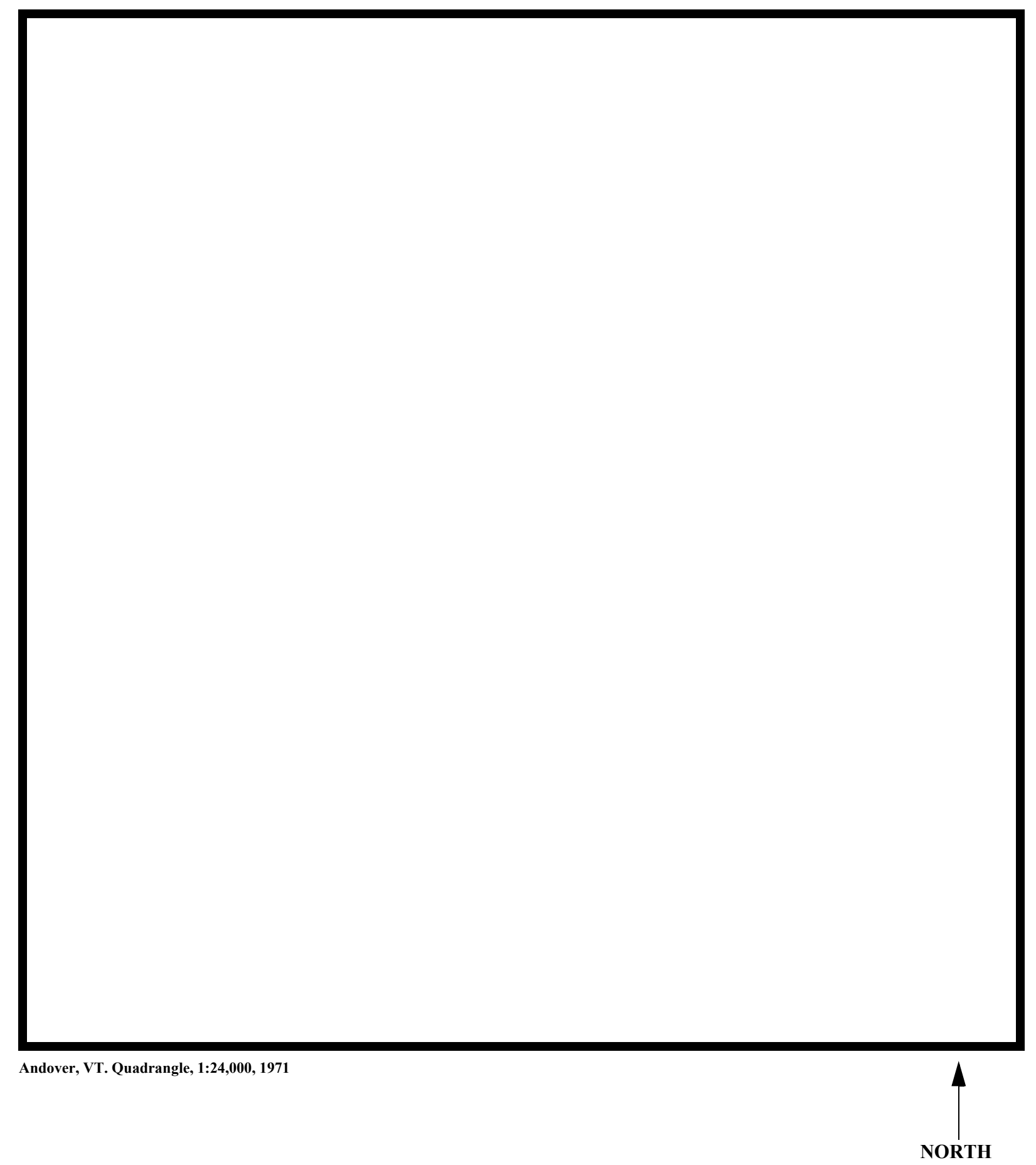

Figure 1. Location of study area on USGS 1:24,000 scale map. 
Figure 2. Location of study area on Vermont Agency of Transportation town highway map. 

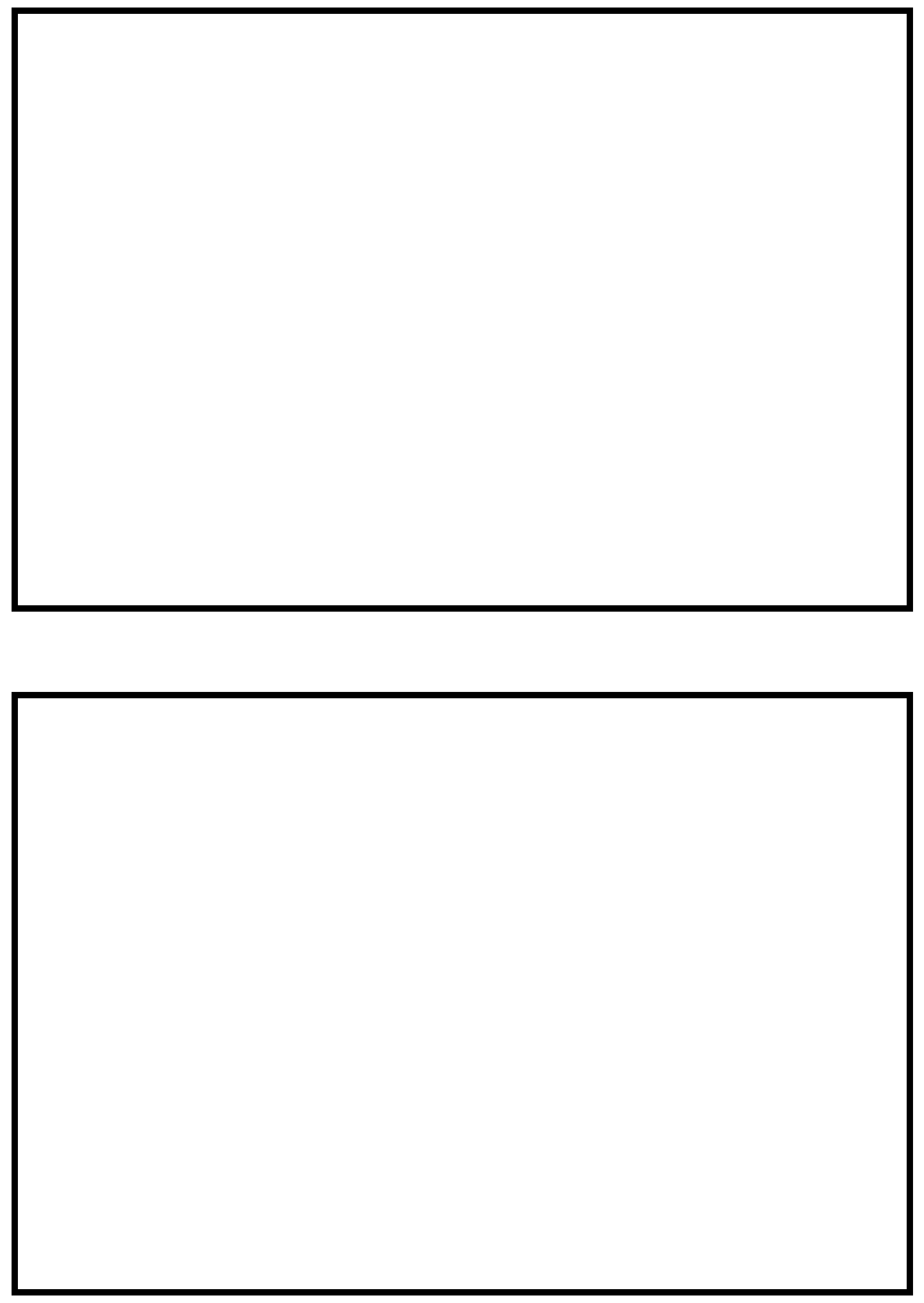

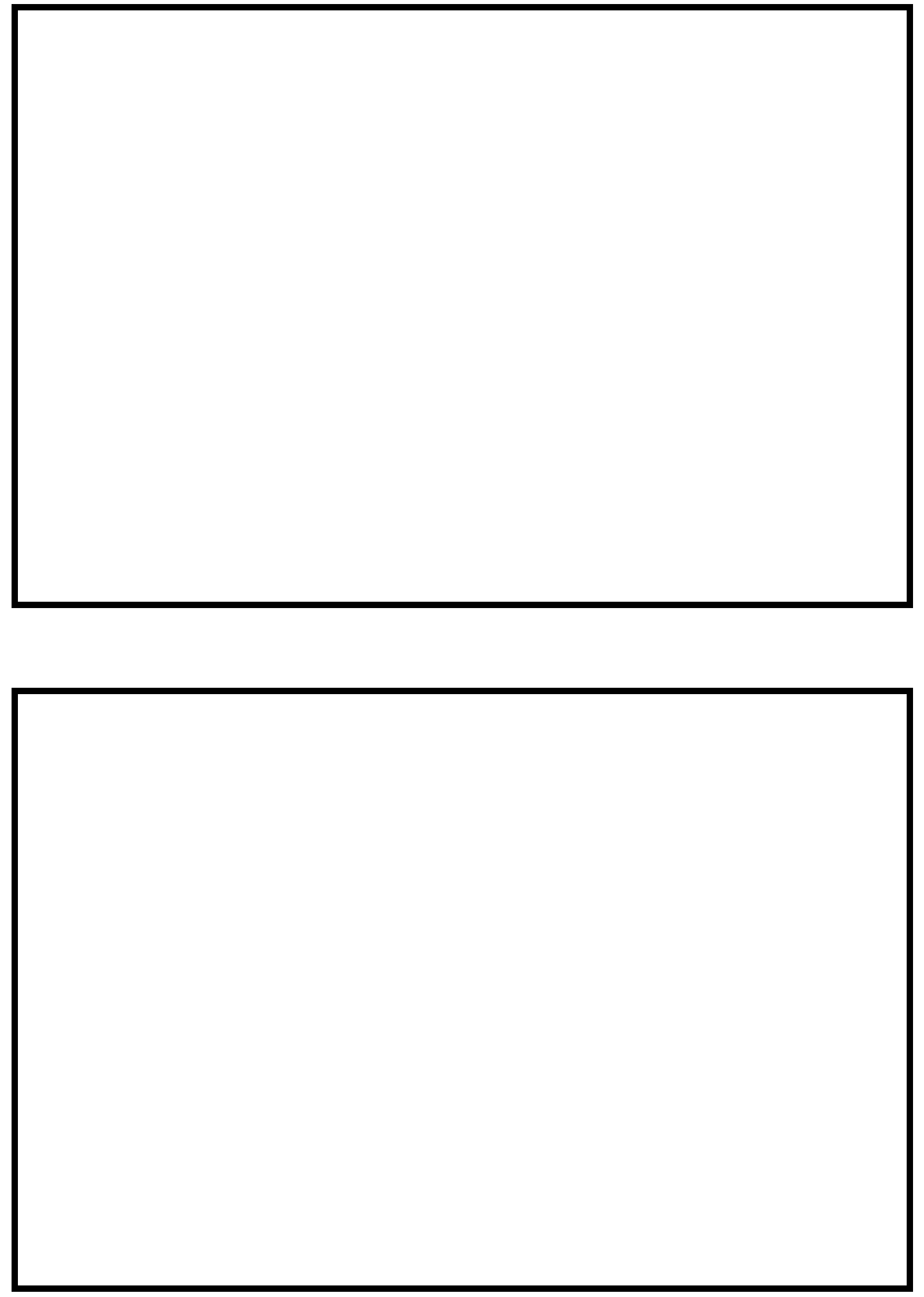


\section{LEVEL II SUMMARY}

\begin{tabular}{llllll} 
Structure Number & ANDOTH00010008 & & \multicolumn{3}{c}{ Andover Branch } \\
Stream & & & & \\
County & Windsor & Road & TH01 & District & 2
\end{tabular}

\section{Description of Bridge}

Bridge length $\stackrel{54}{n} f t \quad$ Bridge width $\stackrel{29.6}{f} \quad$ Max span length $\stackrel{51}{ } f$ Alignment of bridge to road (on curve or straight)

Abutment type Spill-through

Stone fill on abutment?

$$
\text { Yes }
$$

\section{Embankment type}

Curve

namanimtin.. af atan a fill Type-2 along the entire base length of the left and right spill-through slopes and extending up the spill-through slope to abutments..

Abutments and wingwalls are concrete.

$\ldots \ldots+\ldots$

\section{$\mathrm{Y}$}

Is bridge skewed to flood flow according to Y ' survey? Angle

There is a moderate channel bend in both the upstream and downstream, reach.

Debris accumulation on bridge at time of Level I or Level II site visit:

\begin{tabular}{|c|c|c|c|}
\hline & $\begin{array}{c}\text { Date of insnortion } \\
8 / 27 / 96 \\
\end{array}$ & $\begin{array}{l}\text { Percent of almanol } \\
\text { blocked inortzontatly }\end{array}$ & $\begin{array}{l}\text { Percent of } 0 \\
\text { blocked verticatty }\end{array}$ \\
\hline & $8 / 27 / 96$ & 0 & 0 \\
\hline
\end{tabular}

Level II

Moderate. There is some debris caught on boulders and there are trees leaning over the channel upstream.

Potential for debris

A point bar along the left bank has kept flow along the right bank and along the toe of the right Doscriho any, fonturos noar ar at tho hridoo that mav, affort flow (includo ahsorvation dato). abutment spill-through as of 8/27/96. 


\section{Description of the Geomorphic Setting}

General topography The channel is located within a moderate relief valley setting with little to no flood plain.

Geomorphic conditions at bridge site: downstream (DS), upstream (US)

Date of inspection $\quad 8 / 27 / 96$

DS left: $\quad$ Moderately sloped channel bank and overbank

DS right: $\quad$ Moderately sloped channel bank and overbank

US left: $\quad$ Moderately sloped channel bank and overbank

US right: Moderately sloped channel bank and overbank

\section{Description of the Channel}

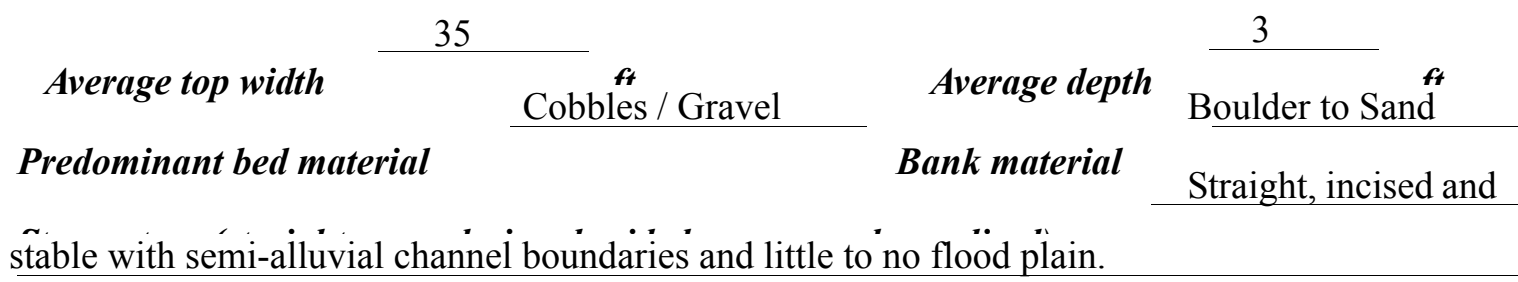

$8 / 27 / 96$

Vegetative co ${ }^{1}$ Grass along immediate banks with trees beyond.

DS left: $\quad$ Grass along immediate banks with trees beyond.

DS right: $\quad$ Grass along immediate banks with trees beyond.

US left: $\quad$ Grass along immediate banks with trees beyond.

US right: $\quad \underline{\mathrm{Y}}$

Do banks appear stable? -

date of observatton.

Flow conditions are

influenced by a point bar on the left bank side of the channel. In addition, some debris is caught Describe any obstructions in channel and date of observation.

on boulders in the channel upstream. 8/27/96 


\title{
Hydrology
}

Drainage area $\stackrel{5.30}{\mathrm{mi}^{2}}$

Percentage of drainage area in physiographic provinces: (approximate)

Physiographic province/section

New England / Green Mountain
Percent of drainage area 100

\begin{abstract}
Is drainage area considered rural or urban? Rural Describe any significant urbanization: None.
\end{abstract}

Is there a

Is there a USGS gage on the stream of interest? USGS gage description

USGS gage number

Gage drainage area $\mathrm{mi}^{2}$

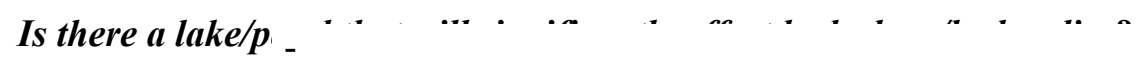

\section{Calculated Discharges $\quad 2,150$ \\ Q100 $\quad \mathrm{ft}^{3} / \mathrm{s}$ \\ $\quad \quad \mathrm{ft}^{3} / \mathrm{s}$}

The 100- and 500-year discharges are based on flood

frequency estimates available from the VTAOT database. These values were selected due to the central tendency of the discharge frequency curve with others which were developed from empirical relationships and graphically extrapolated to the 500-year discharge (Benson, 1962;

Johnson and Tasker, 1974; FHWA, 1983; Potter, 1957a\&b; Talbot, 1887). 


\section{Description of the Water-Surface Profile Model (WSPRO) Analysis}

Datum for WSPRO analysis (USGS survey, sea level, VTAOT plans)

USGS survey

Datum tie between USGS survey and VTAOT plans

USGS arbitrary survey datum and

VTAOT plans' datum are equal to within $+/-1 \mathrm{ft}$.

Description of reference marks used to determine USGS datum. $\quad$ RM1 is a chiseled X on top of the downstream end of the left abutment (elev. $498.41 \mathrm{ft}$, arbitrary survey datum). RM2 is a chiseled X on top of the upstream end of the right abutment (elev. $499.44 \mathrm{ft}$, arbitrary survey datum). RM3 is a State of Vermont brass survey disk on top of the upstream end of the left abutment (elev. $499.75 \mathrm{ft}$, arbitrary survey datum).

\section{Cross-Sections Used in WSPRO Analysis}

\begin{tabular}{|c|c|c|c|}
\hline${ }^{1}$ Cross-section & $\begin{array}{c}\text { Section } \\
\text { Reference } \\
\text { Distance } \\
(\text { SRD) in feet }\end{array}$ & $\begin{array}{c}{ }^{2} \text { Cross-section } \\
\text { development }\end{array}$ & Comments \\
\hline EXTX2 & -198 & 1 & Exit section 2 \\
\hline EXITX & -45 & 1 & Exit section \\
\hline FULLV & 0 & 2 & $\begin{array}{l}\text { Downstream Full-valley } \\
\text { section (Templated from } \\
\text { EXITX) }\end{array}$ \\
\hline BRIDG & 0 & 1 & Bridge section \\
\hline RDWAY & 20 & 1 & Road Grade section \\
\hline APPRO & 82 & 2 & $\begin{array}{l}\text { Modelled Approach sec- } \\
\text { tion (Templated from } \\
\text { APTEM) }\end{array}$ \\
\hline APTEM & 89 & 1 & $\begin{array}{l}\text { Approach section as sur- } \\
\text { veyed (Used as a tem- } \\
\text { plate) }\end{array}$ \\
\hline
\end{tabular}

${ }^{1}$ For location of cross-sections see plan-view sketch included with Level I field form, Appendix E. For more detail on how cross-sections were developed see WSPRO input file. 


\section{Data and Assumptions Used in WSPRO Model}

Hydraulic analyses of the reach were done by use of the Federal Highway Administration's WSPRO step-backwater computer program (Shearman and others, 1986, and Shearman, 1990). The analyses reported herein reflect conditions existing at the site at the time of the study. Furthermore, in the development of the model it was necessary to assume no accumulation of debris or ice at the site. Results of the hydraulic model are presented in the Bridge Hydraulic Summary, Appendix B, and figure 7.

Channel roughness factors (Manning's " $n$ ") used in the hydraulic model were estimated using field inspections at each cross section following the general guidelines described by Arcement and Schneider (1989). Final adjustments to the values were made during the modelling of the reach. Channel " $\mathrm{n}$ " values for the reach ranged from 0.045 to 0.050 , and overbank " $\mathrm{n}$ " values ranged from 0.090 to 0.125 .

Normal depth at the exit section (EXITX) was assumed as the starting water surface. This depth was computed by use of the slope-conveyance method outlined in the user's manual for WSPRO (Shearman, 1990). The slope used was $0.012 \mathrm{ft} / \mathrm{ft}$ which was estimated from the topographic map (U.S. Geological Survey, 1971).

The surveyed approach section (APTEM) was moved along the approach channel slope $(0.013 \mathrm{ft} / \mathrm{ft})$ to establish the modelled approach section (APPRO), one bridge length upstream of the upstream face as recommended by Shearman and others (1986). This approach also provides a consistent method for determining scour variables. 


\section{Bridge Hydraulics Summary}

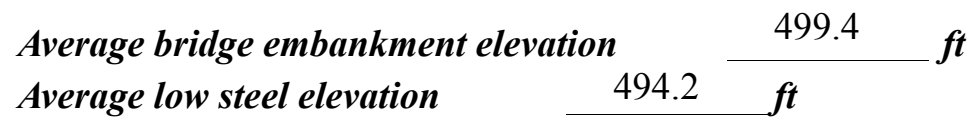

100-year discharge $\quad 1,450 \quad \mathrm{ft}^{3} / \mathrm{s}$

Water-surface elevation in bridge opening $\quad 494.9 \quad f t$

Road overtopping? ___ Y Discharge over road __ $292 \quad \mathrm{ft}^{3} / \mathrm{s}$

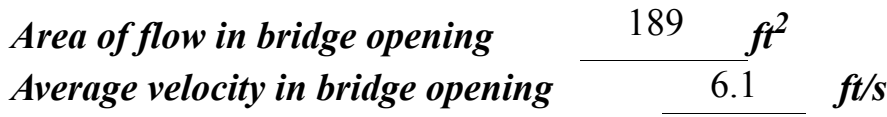

Maximum WSPRO tube velocity at bridge $\quad 8.4 \quad \mathrm{ft} / \mathrm{s}$

Water-surface elevation at Approach section with bridge 495.1

Water-surface elevation at Approach section without bridge $\quad 494.4$

Amount of backwater caused by bridge $\quad 0.7 \quad$ it

500-year discharge $\quad 2,150 \quad \mathrm{ft}^{3} / \mathrm{s}$

Water-surface elevation in bridge opening

$494.3 \mathrm{ft}$

Road overtopping? ___ Y Discharge over road __ $456 \quad \mathrm{ft}^{3} / \mathrm{s}$

Area of flow in bridge opening $\quad 190 \quad \mathrm{ft}^{2}$

Average velocity in bridge opening $8.9 \mathrm{ft} / \mathrm{s}$

Maximum WSPRO tube velocity at bridge 11.4 's

Water-surface elevation at Approach section with bridge 495.7

Water-surface elevation at Approach section without bridge $\quad 495.60$

Amount of backwater caused by bridge $\quad$\begin{tabular}{lll}
$0.1 \quad f t$ \\
\hline
\end{tabular}

Incipient overtopping discharge $\quad 410 \quad \mathrm{ft}^{3} / \mathrm{s}$

Water-surface elevation in bridge opening $490.7 \quad t$

Area of flow in bridge opening $\quad 55 \quad \mathrm{ft}^{2}$

Average velocity in bridge opening $\quad 7.5 \mathrm{ft} / \mathrm{s}$

Maximum WSPRO tube velocity at bridge $\quad 9.1 \quad \mathrm{ft} / \mathrm{s}$

Water-surface elevation at Approach section with bridge 493.5.

Water-surface elevation at Approach section without bridge $\quad 492.0$

Amount of backwater caused by bridge $\quad$\begin{tabular}{l}
1.5 it \\
\hline
\end{tabular} 


\section{Scour Analysis Summary}

\section{Special Conditions or Assumptions Made in Scour Analysis}

Scour depths were computed using the general guidelines described in Hydraulic Engineering Circular 18 (Richardson and others, 1995). Scour depths were calculated assuming an infinite depth of erosive material and a homogeneous particle-size distribution. The results of the scour analysis are presented in tables 1 and 2 and a graph of the scour depths is presented in figure 8 .

Contraction scour for the incipient roadway-overtopping discharge was computed by use of Laursen's clear-water contraction scour equation (Richardson and others, 1995, p. 32, equation 20). The 100-year discharge resulted in unsubmerged orifice flow with road overflow while the 500-year discharge resulted in submerged orifice flow with road overflow. Contraction scour at bridges with orifice flow is best estimated by use of the Chang pressure-flow scour equation (oral communication, J. Sterling Jones, October 4, 1996). Thus, the Chang scour equation (Richardson and others, 1995, p. 145-146) was

applied to compute contraction scour for the 100- and 500-year events. The results of Laursen's clear-water and live-bed contraction scour equations were also computed for these discharges and can be found in appendix F. The 500-year discharge model resulted in the worst case contraction scour with a scour depth of $0.1 \mathrm{ft}$. The computed depths to streambed armoring suggest armoring will not limit the depth of contraction scour.

Abutment scour was computed by use of the Froehlich equation (Richardson and others, 1995, p. 48, equation 28). Variables for the Froehlich equation include the Froude number of the flow approaching the embankments, the length of the embankment blocking flow, and the depth of flow approaching the embankment less any roadway overtopping. Because scour processes on the spill-through embankment material is uncertain, the scour depth at the vertical concrete abutment walls is unknown. Therefore, the total scour depths were applied for the entire spill-through embankment below the elevation at the toe of each embankment and extended to the vertical concrete abutment wall as shown in figure 8 . 


\section{Scour Results}

100-yr discharge 500-yr discharge

Contraction scour:

(Scour depths in feet)

Main channel

Live-bed scour

Clear-water scour

Depth to armoring

Left overbank

Right overbank

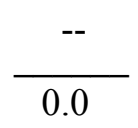

$0.2^{-}$
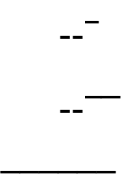

Local scour:

Abutment scour

Left abutment

Right abutment

Pier scour

Pier 1

Pier 2

Pier 3
6.2

$3.8-$
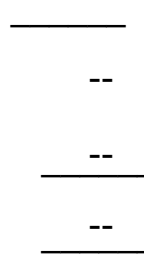

8.1

$4.6-$

$2.1-$

Riprap Sizing overtopping discharge
Incipient 


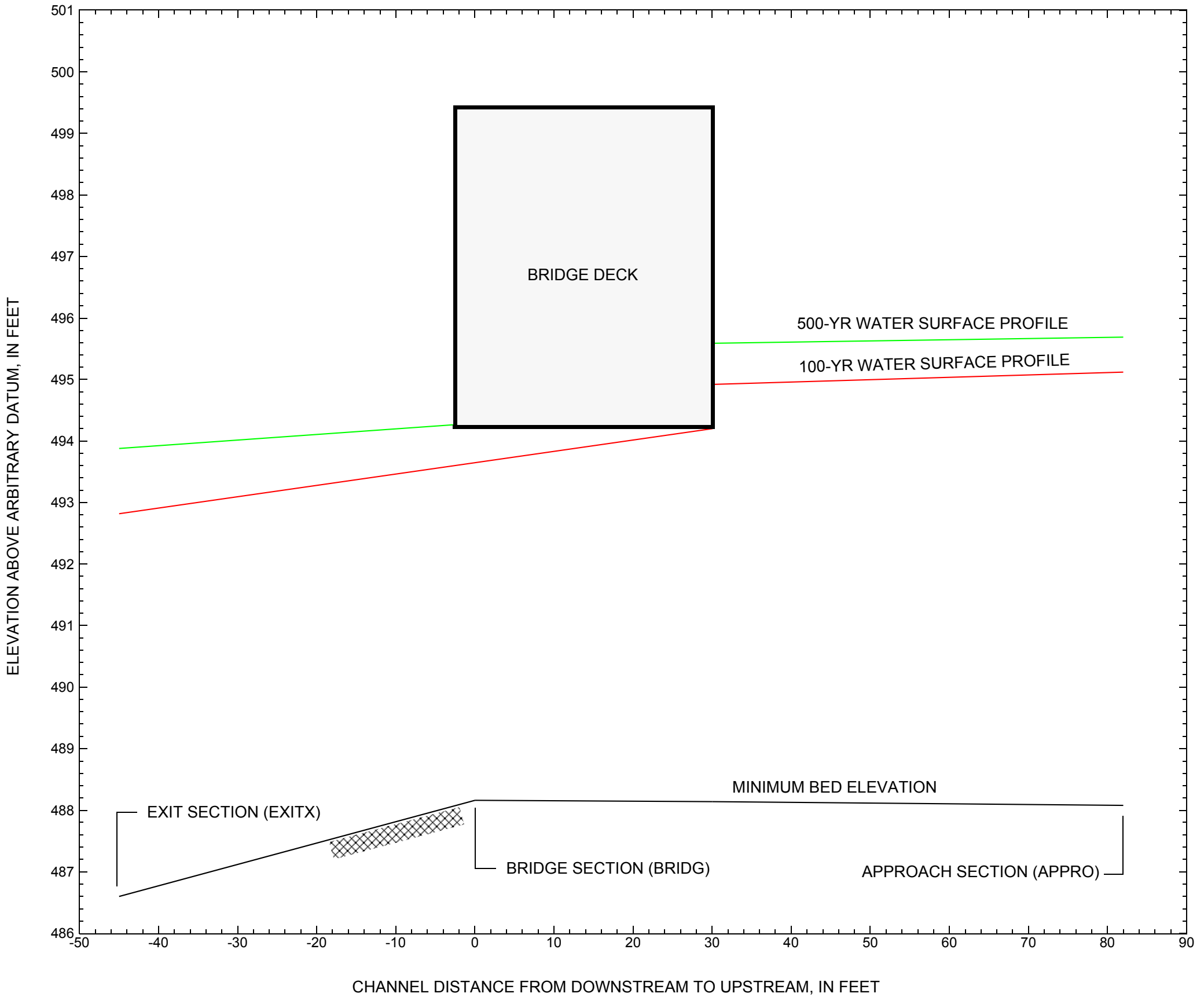

Figure 7. Water-surface profiles for the 100- and 500-yr discharges at structure ANDOTH00010008 on Town Highway 1, crossing the Andover Branch, Andover, Vermont. 


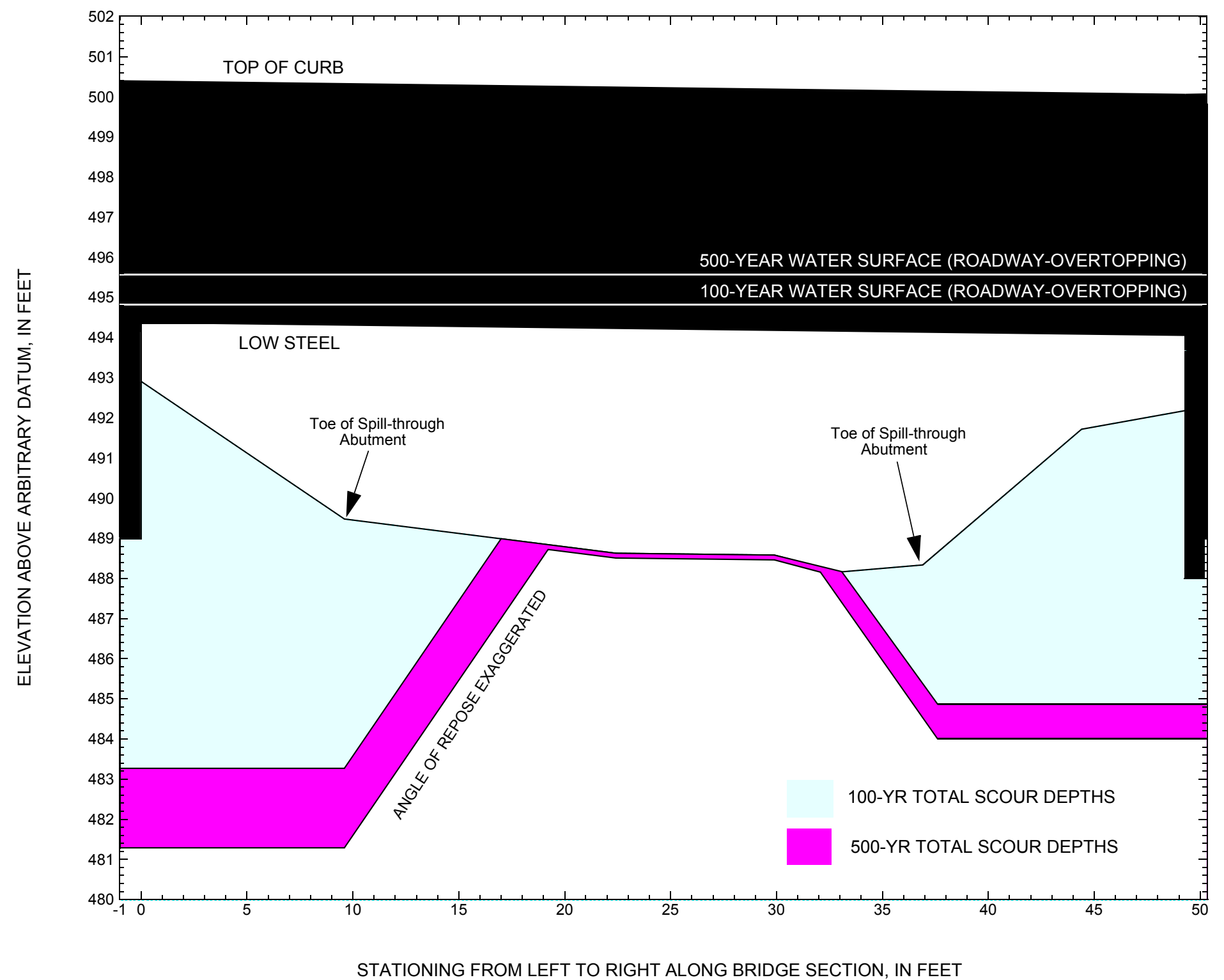

Figure 8. Scour elevations for the 100-yr and 500-yr discharges at structure ANDOTH00010008 on Town Highway 1, crossing the Andover Branch, Andover, Vermont. 
Table 1. Remaining footing/pile depth at abutments for the 100-year discharge at structure ANDOTH00010008 on Town Highway 1, crossing the Andover Branch, Andover, Vermont.

[VTAOT, Vermont Agency of Transportation; --,no data]

\begin{tabular}{|c|c|c|c|c|c|c|c|c|c|c|c|}
\hline Description & Station ${ }^{1}$ & $\begin{array}{l}\text { VTAOT } \\
\text { minimum } \\
\text { bridge seat } \\
\text { elevation } \\
\text { (feet) }\end{array}$ & $\begin{array}{c}\text { Surveyed } \\
\text { minimum } \\
\text { low-chord } \\
\text { elevation } \\
\text { (feet) }\end{array}$ & $\begin{array}{c}\text { Bottom of } \\
\text { footing } \\
\text { elevation } \\
\text { (feet) }\end{array}$ & $\begin{array}{c}\text { Channel } \\
\text { elevation at } \\
\text { abutment/ } \\
\text { pier }^{2} \\
\text { (feet) }\end{array}$ & $\begin{array}{l}\text { Contraction } \\
\text { scour depth } \\
\text { (feet) }\end{array}$ & $\begin{array}{l}\text { Abutment } \\
\text { scour } \\
\text { depth } \\
\text { (feet) }\end{array}$ & $\begin{array}{l}\text { Pier } \\
\text { scour } \\
\text { depth } \\
\text { (feet) }\end{array}$ & $\begin{array}{l}\text { Depth of } \\
\text { total scour } \\
\text { (feet) }\end{array}$ & $\begin{array}{c}\text { Elevation of } \\
\text { scour }^{2} \\
\text { (feet) }\end{array}$ & $\begin{array}{c}\text { Remaining } \\
\text { footing/pile } \\
\text { depth } \\
\text { (feet) }\end{array}$ \\
\hline \multicolumn{12}{|c|}{100 -yr. discharge is 1,450 cubic-feet per second } \\
\hline Left abutment & 0.0 & 495.3 & 494.4 & 489 & 492.9 & 0.0 & -- & -- & -- & -- & -6 \\
\hline Toe of Labut & 9.6 & -- & -- & -- & 489.5 & 0.0 & 6.2 & -- & 6.2 & 483.3 & -- \\
\hline Toe of Rabut & 37.6 & -- & -- & -- & 488.7 & 0.0 & 3.8 & -- & 3.8 & 484.9 & -- \\
\hline Right abutment & 49.3 & 495.0 & 494.0 & 488 & 492.2 & 0.0 & -- & -- & -- & -- & -3 \\
\hline
\end{tabular}

1.Measured along the face of the most constricting side of the bridge.

2.Arbitrary datum for this study.

Table 2. Remaining footing/pile depth at abutments for the 500-year discharge at structure ANDOTH00010008 on Town Highway 1, crossing the Andover Branch, Andover, Vermont.

[VTAOT, Vermont Agency of Transportation; --, no data]

\begin{tabular}{|c|c|c|c|c|c|c|c|c|c|c|c|}
\hline Description & Station $^{1}$ & $\begin{array}{l}\text { VTAOT } \\
\text { minimum } \\
\text { bridge seat } \\
\text { elevation } \\
\text { (feet) }\end{array}$ & $\begin{array}{l}\text { Surveyed } \\
\text { minimum } \\
\text { low-chord } \\
\text { elevation } \\
\quad \text { (feet) }\end{array}$ & $\begin{array}{c}\text { Bottom of } \\
\text { footing } \\
\text { elevation } \\
\text { (feet) }\end{array}$ & $\begin{array}{c}\text { Channel } \\
\text { elevation at } \\
\text { abutment/ } \\
\text { pier }^{2} \\
\text { (feet) }\end{array}$ & $\begin{array}{l}\text { Contraction } \\
\text { scour depth } \\
\text { (feet) }\end{array}$ & $\begin{array}{l}\text { Abutment } \\
\text { scour } \\
\text { depth } \\
\text { (feet) }\end{array}$ & $\begin{array}{l}\text { Pier } \\
\text { scour } \\
\text { depth } \\
\text { (feet) }\end{array}$ & $\begin{array}{l}\text { Depth of } \\
\text { total scour } \\
\text { (feet) }\end{array}$ & $\begin{array}{c}\text { Elevation of } \\
\text { scour }^{2} \\
\text { (feet) }\end{array}$ & $\begin{array}{c}\text { Remaining } \\
\text { footing/pile } \\
\text { depth } \\
\text { (feet) }\end{array}$ \\
\hline \multicolumn{12}{|c|}{500 -yr. discharge is 2,150 cubic-feet per second } \\
\hline Left abutment & 0.0 & 495.3 & 494.4 & 489 & 492.9 & 0.1 & -- & -- & -- & -- & -8 \\
\hline Toe of Labut & 9.6 & -- & -- & -- & 489.5 & 0.1 & 8.1 & -- & 8.2 & 481.3 & -- \\
\hline Toe of Rabut & 37.6 & -- & -- & -- & 488.7 & 0.1 & 4.6 & -- & 4.7 & 484.0 & -- \\
\hline Right abutment & 49.3 & 495.0 & 494.0 & 488 & 492.2 & 0.1 & -- & -- & -- & -- & -4 \\
\hline
\end{tabular}

1.Measured along the face of the most constricting side of the bridge.

2.Arbitrary datum for this study. 


\section{SELECTED REFERENCES}

Arcement, G.J., Jr., and Schneider, V.R., 1989, Guide for selecting Manning's roughness coefficients for natural channels and flood plains: U.S. Geological Survey Water-Supply Paper 2339, 38 p.

Barnes, H.H., Jr., 1967, Roughness characteristics of natural channels: U.S. Geological Survey Water-Supply Paper 1849,213 p.

Benson, M. A., 1962, Factors Influencing the Occurrence of Floods in a Humid Region of Diverse Terrain: U.S. Geological Survey WaterSupply Paper 1580-B, 64 p.

Brown, S.A. and Clyde, E.S., 1989, Design of riprap revetment: Federal Highway Administration Hydraulic Engineering Circular No. 11, Publication FHWA-IP-89-016, 156 p.

Federal Highway Administration, 1983, Runoff estimates for small watersheds and development of sound design: Federal Highway Administration Report FHWA-RD-77-158

Froehlich, D.C., 1989, Local scour at bridge abutments in Ports, M.A., ed., Hydraulic Engineering--Proceedings of the 1989 National Conference on Hydraulic Engineering: New York, American Society of Civil Engineers, p. 13-18.

Hayes, D.C.,1993, Site selection and collection of bridge-scour data in Delaware, Maryland, and Virginia: U.S. Geological Survey WaterResources Investigation Report 93-4017, 23 p.

Interagency Advisory Committee on Water Data, 1982, Guidelines for determining flood flow frequency: U.S. Geological Survey, Bulletin 17B of the Hydrology Subcommittee, 190 p.

Johnson, C.G. and Tasker, G.D.,1974, Progress report on flood magnitude and frequency of Vermont streams: U.S. Geological Survey OpenFile Report 74-130, 37 p.

Lagasse, P.F., Schall, J.D., Johnson, F., Richardson, E.V., Chang, F., 1995, Stream Stability at Highway Structures: Federal Highway Administration Hydraulic Engineering Circular No. 20, Publication FHWA-IP-90-014, 144 p.

Laursen, E.M., 1960, Scour at bridge crossings: Journal of the Hydraulics Division, American Society of Civil Engineers, v. 86, no. HY2, p. 39-53.

Potter, W. D., 1957a, Peak rates of runoff in the Adirondack, White Mountains, and Maine woods area, Bureau of Public Roads

Potter, W. D., 1957b, Peak rates of runoff in the New England Hill and Lowland area, Bureau of Public Roads

Richardson, E.V. and Davis, S.R., 1995, Evaluating scour at bridges: Federal Highway Administration Hydraulic Engineering Circular No. 18, Publication FHWA-IP-90-017, 204 p.

Richardson, E.V., Simons, D.B., and Julien, P.Y., 1990, Highways in the river environment: Federal Highway Administration Publication FHWA-HI-90-016.

Ritter, D.F., 1984, Process Geomorphology: W.C. Brown Co., Debuque, Iowa, 603 p.

Shearman, J.O., 1990, User's manual for WSPRO--a computer model for water surface profile computations: Federal Highway Administration Publication FHWA-IP-89-027, 187 p.

Shearman, J.O., Kirby, W.H., Schneider, V.R., and Flippo, H.N., 1986, Bridge waterways analysis model; research report: Federal Highway Administration Publication FHWA-RD-86-108, 112 p.

Talbot, A.N., 1887, The determination of water-way for bridges and culverts.

U.S. Department of Transportation, 1993, Stream stability and scour at highway bridges, Participant Workbook: Federal Highway Administration Publication FHWA HI-91-011.

U.S. Geological Survey, 1971, Andover, Vermont 7.5 Minute Series quadrangle map: U.S. Geological Survey Topographic Maps, Scale $1: 24,000$. 


\section{APPENDIX A: \\ WSPRO INPUT FILE}




\section{WSPRO INPUT FILE}

AS

GT

SA

*

HP 1 BRIDG

HP 2 BRIDG

HP 2 RDWAY

HP 1 APPRO

HP 2 APPRO

HP 1 BRIDG

HP 2 BRIDG

U.S. Geological Survey WSPRO Input File ando008.wsp Hydraulic analysis for structure ANDOTH00010008 Date: 12-FEB-97 Bridge 8 over Andover Brook in Andover, Vt. RF

* $* 0.002$

$\begin{array}{lllllllllllllllllllll}6 & 29 & 30 & 552 & 553 & 551 & 5 & 16 & 17 & 13 & 3 & * & 15 & 14 & 23 & 21 & 11 & 12 & 4 & 7 & 3\end{array}$

$1450.0 \quad 2150.0 \quad 410.0$

$0.0120 .012 \quad 0.012$

EXTX2 $-198 \quad 0$.

$-139.9,503.52-123.8,494.10$

$11.0,485.93 \quad 18.2,485.81$

$30.9,485.77 \quad 32.0,486.49$

$-90.3,492.41$

$0.0,491.09$

$23.6,484.76 \quad 28.1,485.27$

$40.7,488.89 \quad 58.3,490.70$

$71.9,492.56$

$90.3,495.80$

$119.9,495.80$

$170.0,495.80$

$178.6,498.63$

$\begin{array}{lll}0.125 & 0.050 & 0.100\end{array}$

$$
0.0 \quad 40.7
$$

EXITX $-45 \quad 0$.

$-139.9,505.36-123.8,495.94$

$11.0,487.77 \quad 18.2,487.65$

$30.9,487.61 \quad 40.7,490.73$

$90.3,497.64 \quad 119.9,497.64$

$178.6,500.47$

$-90.3,494.25$

$0.0,492.93$

$23.6,486.60$

$28.1,487.11$

$58.3,492.54$

$71.9,494.40$

$145.0,491.49$

$170.0,497.64$
0.050

40.7

0.100

0.125

0.0

0.019

\section{SRD LSEL}

$\begin{array}{lr}0 & 494.20\end{array}$

$22.4,488.63$

$37.6,488.66$

$49.3,494.04$

0.045

3

$$
39.2
$$

\section{SRD}

EMBWID $-207.0,525.00$.

$-2.0,500.48$

$51.5,499.27$

$146.0,500.50$

APTEM

$$
-218.0,520.00
$$

$0.0,492.21$

$18.6,488.55$

$27.6,491.56$

$$
-217
$$

$217.4,497.81$
$6.8,489.54$
$21.6,488.17$

$47.6,494.63$

$-94.9,494.82$

$12.7,489.18$

$24.1,488.51$

$75.5,498.34$ $\begin{array}{rr}9.6, & 489.48 \\ 36.9, & 488.34 \\ 49.2, & 493.67\end{array}$

$-2.3,499.55$

$51.2,500.14$

$138.6,498.14$

$-16.6,494.22$

$14.8,488.77$

$25.1,489.16$

$103.2,507.93$ 


\section{APPENDIX B: \\ WSPRO OUTPUT FILE}




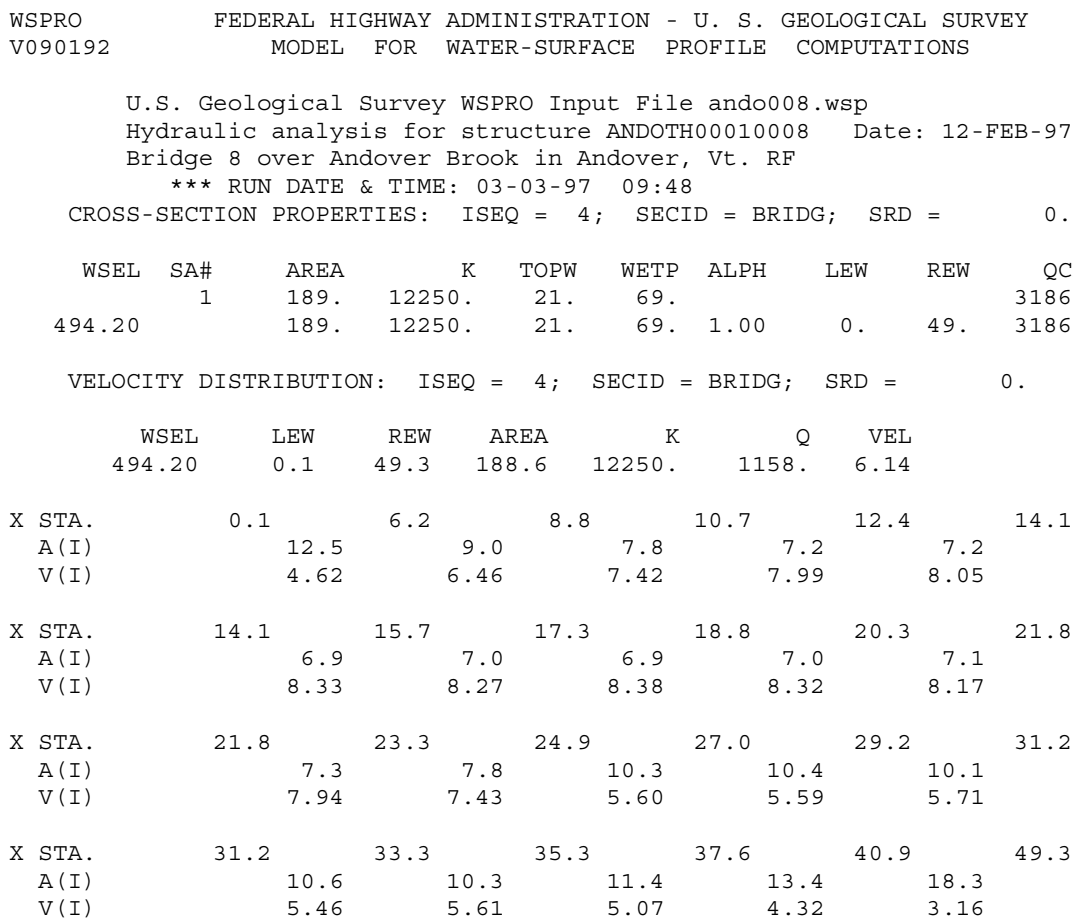

VELOCITY DISTRIBUTION: ISEQ $=5 ; \operatorname{SECID~}=$ RDWAY $\quad \operatorname{SRD}=20$.

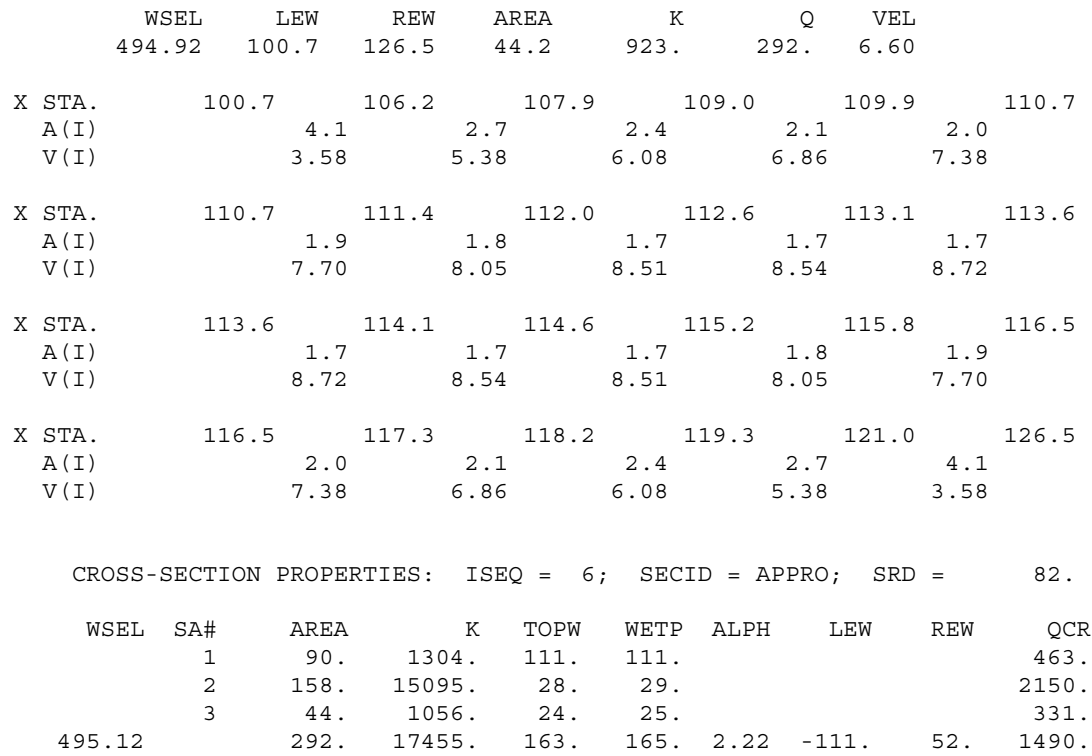

VELOCITY DISTRIBUTION: ISEQ $=6 ; \operatorname{SECID~}=$ APPRO; $\quad \mathrm{SRD}=82$.

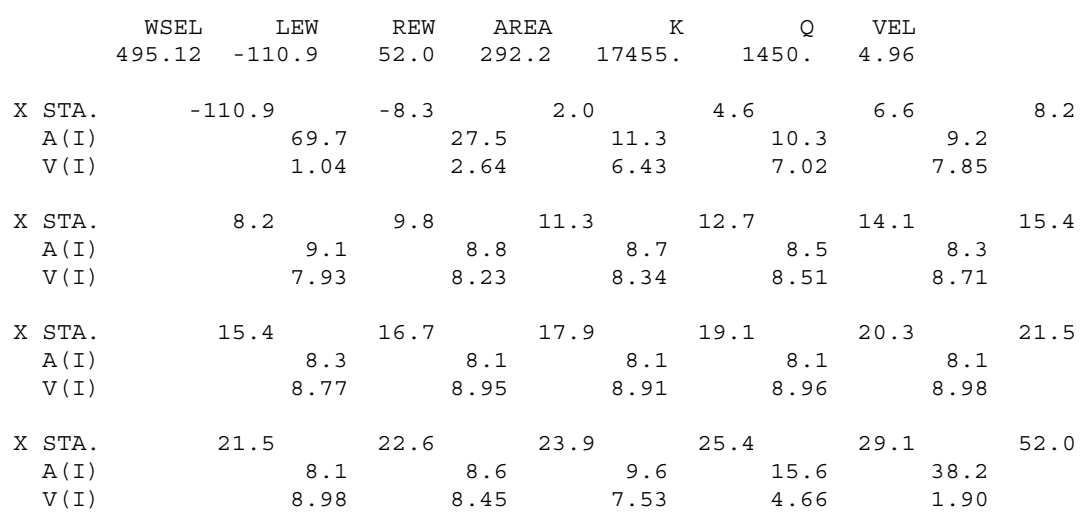




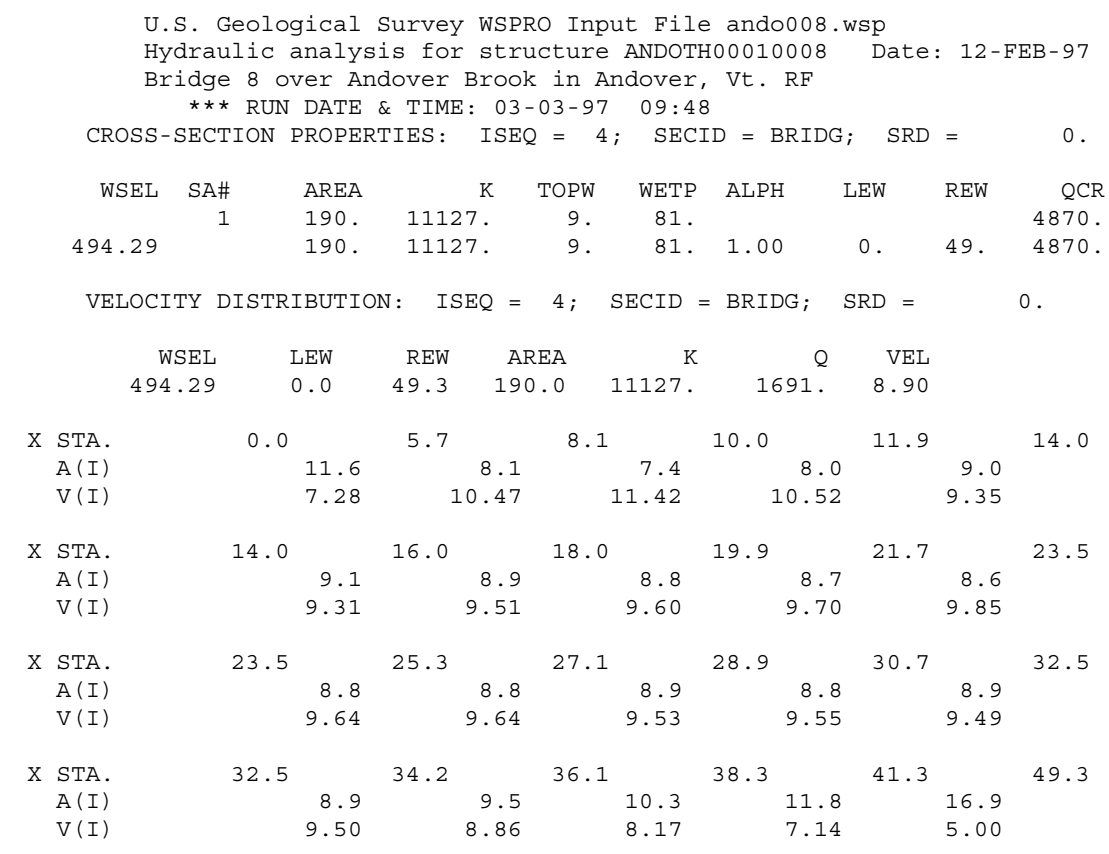

VELOCITY DISTRIBUTION : ISEQ $=5 ;$ SECID $=$ RDWAY $; \quad$ SRD $=$

20.

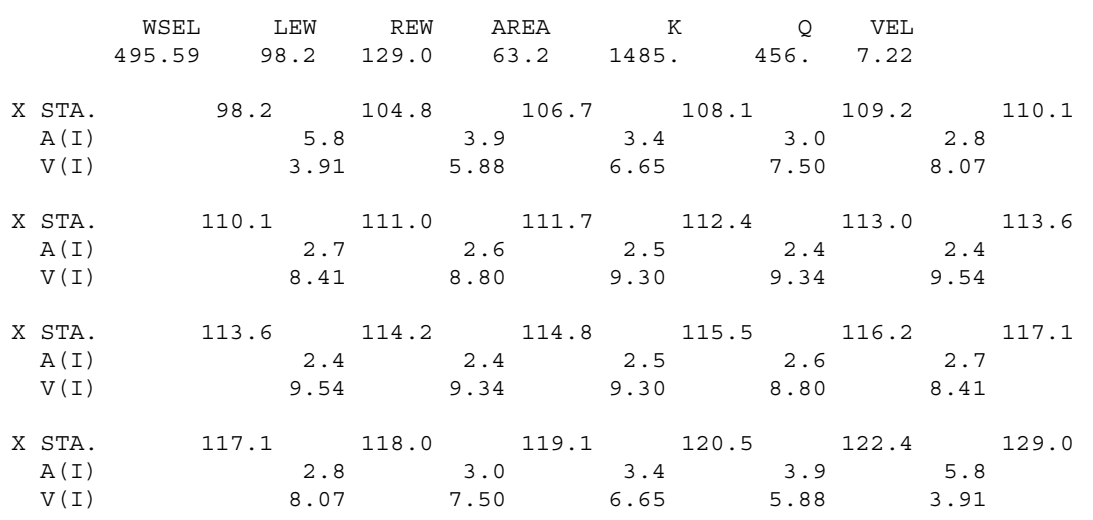

CROSS-SECTION PROPERTIES: ISEQ $=6 ;$ SECID $=$ APPRO; $\quad$ SRD $=\quad 82$.

\begin{tabular}{|c|c|c|c|c|c|c|c|c|c|}
\hline \multirow[t]{4}{*}{ WSEL } & SA\# & AREA & $\mathrm{K}$ & TOPW & WETP & $\mathrm{ALPH}$ & LEW & REW & QCR \\
\hline & 1 & 160. & 2983. & 134. & 134. & & & & 993. \\
\hline & 2 & 174. & 17679 . & 28 & 29. & & & & 2478 \\
\hline & 3 & 59. & 1556 . & 29. & 29 . & & & & 477 . \\
\hline
\end{tabular}

495.69 393. 22218. $191 . \quad 193.2 .60-134 . \quad$ 56. 1986.

VELOCITY DISTRIBUTION: ISEQ $=6 ; \quad$ SECID $=$ APPRO $; \quad$ SRD $=\quad 82$.

\begin{tabular}{|c|c|c|c|c|c|c|c|}
\hline & & WSEL & REW & EA & $Q$ & VEL & \\
\hline & & 495.69 & 56.3 & 22218 . & 2150 . & 5.47 & \\
\hline $\mathrm{X}$ & STA. & -134.3 & -45.9 & -10.0 & 1.3 & 4.3 & 6.4 \\
\hline & $A(I)$ & 75.2 & 55.4 & 34.7 & 14.0 & 12.0 & \\
\hline & $V(I)$ & 1.43 & 1.94 & 3.10 & 7.68 & 8.94 & \\
\hline $\mathrm{X}$ & STA. & 6.4 & 8.2 & 9.8 & 11.5 & 13.1 & 14.5 \\
\hline & $A(I)$ & 11.1 & 10.4 & 10.7 & 10.4 & 10.1 & \\
\hline & $V(I)$ & 9.67 & 10.31 & 10.03 & 10.38 & 10.67 & \\
\hline $\mathrm{X}$ & STA. & 14.5 & 16.0 & 17.3 & 18.7 & 20.0 & 21.3 \\
\hline & $A(I)$ & 10.0 & 9.8 & 9.8 & 9.8 & 9.5 & \\
\hline & $V(I)$ & 10.75 & 10.96 & 10.92 & 11.02 & 11.31 & \\
\hline $\mathrm{X}$ & STA. & 21.3 & 22.6 & 24.0 & 25.8 & 30.8 & 56.3 \\
\hline & $A(I)$ & 10.0 & 10.1 & 12.1 & 22.0 & 45.9 & \\
\hline & $\mathrm{V}(\mathrm{I})$ & 10.72 & 10.65 & 8.88 & 4.89 & 2.34 & \\
\hline
\end{tabular}


WSPRO OUTPUT FILE (continued)

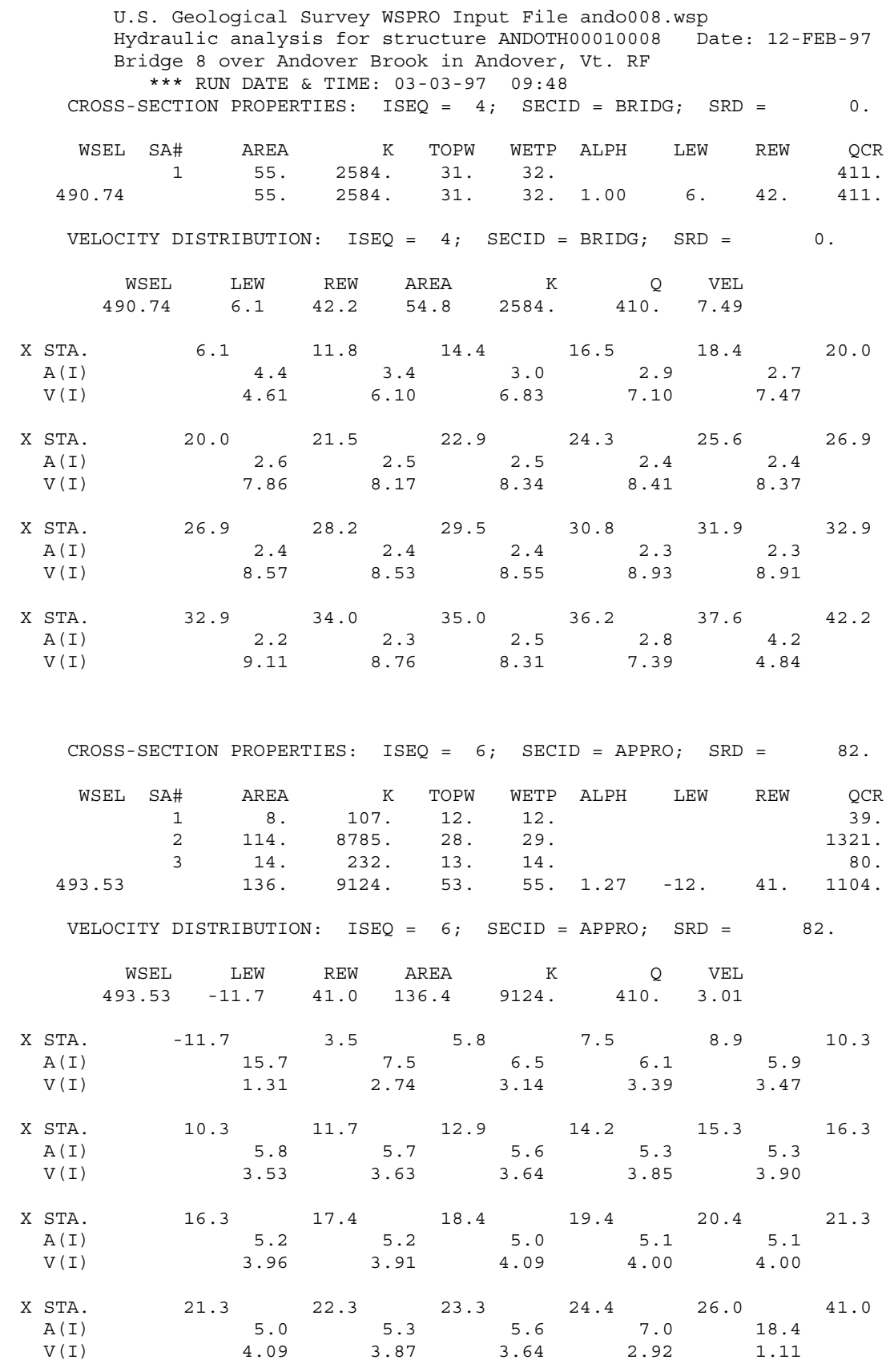


WSPRO OUTPUT FILE (continued)

WSPRO

V090192
FEDERAL HIGHWAY ADMINISTRATION - U. S. GEOLOGICAL SURVEY

MODEL FOR WATER-SURFACE PROFILE COMPUTATIONS

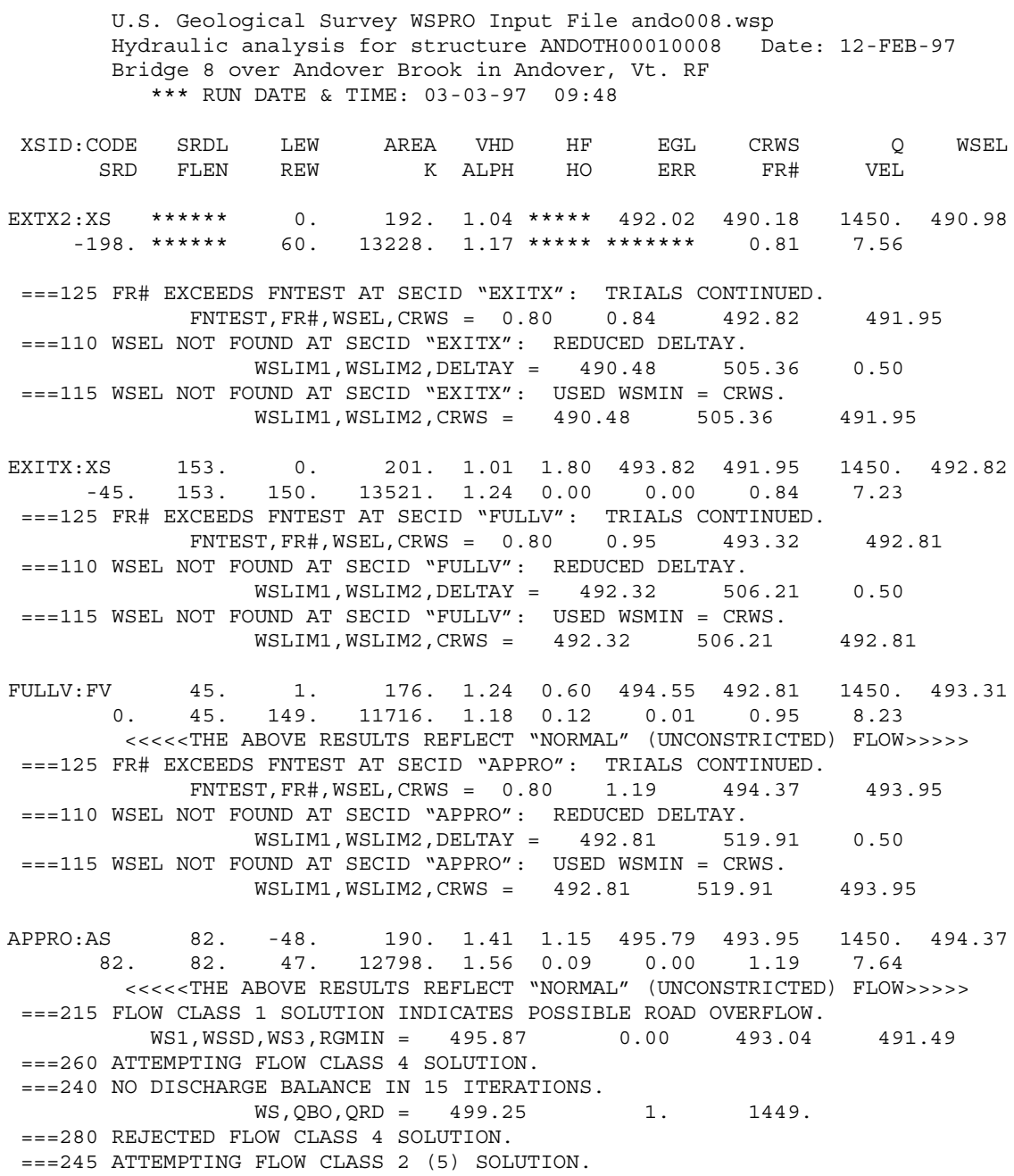


WSPRO OUTPUT FILE (continued)

\author{
U.S. Geological Survey WSPRO Input File ando008.wsp \\ Hydraulic analysis for structure ANDOTH00010008 Date: 12-FEB-97 \\ Bridge 8 over Andover Brook in Andover, Vt. RF \\ *** RUN DATE \& TIME: 03-03-97 09:48 \\ FIRST USER DEFINED TABLE.

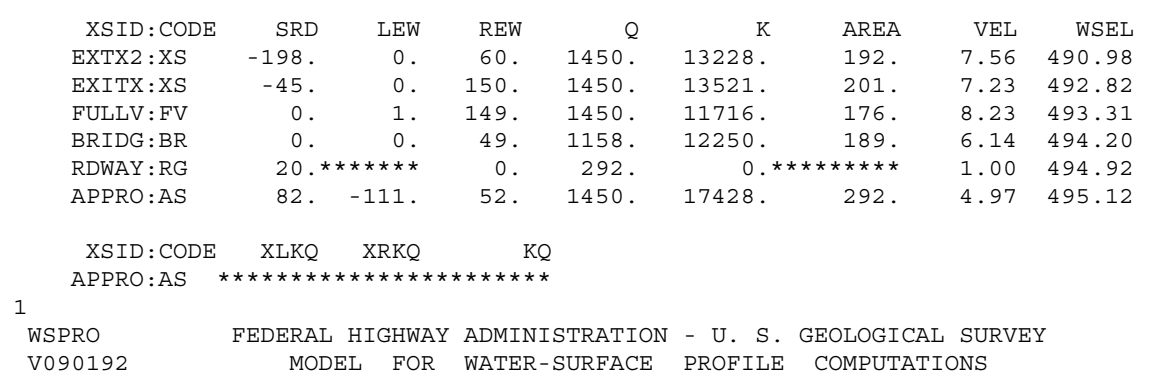 \\ U.S. Geological Survey WSPRO Input File ando008.wsp \\ Hydraulic analysis for structure ANDOTH00010008 Date: 12-FEB-97 \\ Bridge 8 over Andover Brook in Andover, Vt. RF \\ *** RUN DATE \& TIME: 03-03-97 09:48 \\ SECOND USER DEFINED TABLE.

\begin{tabular}{|c|c|c|c|c|c|c|c|c|c|}
\hline XSID : CODE & CRWS & FR\# & YMIN & YMAX & $\mathrm{HF}$ & $\mathrm{HO}$ & VHD & EGL & \\
\hline EXTX2:XS & 490.18 & 0.81 & 484.76 & 503.52 * * & 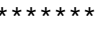 & $\star \star \star \star \star$ & 1.04 & 192.02 & 490. \\
\hline$X I$ & 1.95 & .84 & 36.60 & 505.36 & 1.80 & 0.00 & 1.01 & 93.82 & 92 \\
\hline UL & & & & 06 & 0.60 & & 24 & & \\
\hline RIDG : B & 492.54 & 0.55 & 488.1 & $494.36 * *$ & $\star \star \star \star \star \star * \star *$ & $\star \star \star \star \star *$ & 0.59 & 4.79 & 994 \\
\hline DWA & 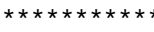 & $\star \star \star \star * *$ & 491. & 525.00 & $0.36 * *$ & 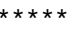 & 0.85 & 495.61 & 494. \\
\hline PPRO : AS & 493.95 & 0.98 & 488.08 & 519.91 & 0.36 & 0.00 & 0.85 & 495.97 & 495. \\
\hline
\end{tabular} \\ 1 \\ WSPRO \\ FEDERAL HIGHWAY ADMINISTRATION - U. S. GEOLOGICAL SURVEY \\ V090192 MODEL FOR WATER-SURFACE PROFILE COMPUTATIONS

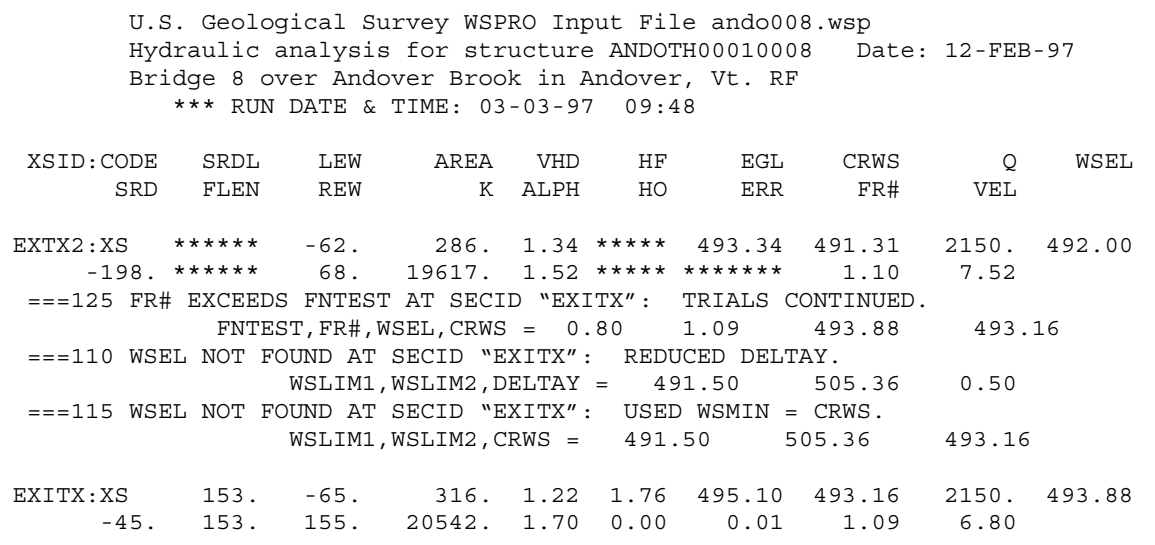 \\ $===125$ FR\# EXCEEDS FNTEST AT SECID "FULLV": TRIALS CONTINUED.

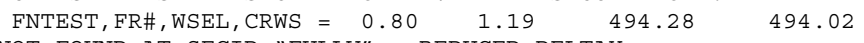 \\ $==110$ WSEL NOT FOUND AT SECID "FULLV": REDUCED DELTAY. \\ WSLIM1, WSLIM2, DELTAY $=\begin{array}{lll}493.38 & 506.21 & 0.50\end{array}$ \\ $==115$ WSEL NOT FOUND AT SECID "FULLV": USED WSMIN = CRWS. \\ WSLIM1, WSLIM2, CRWS $=493.38 \quad 506.21 \quad 494.02$

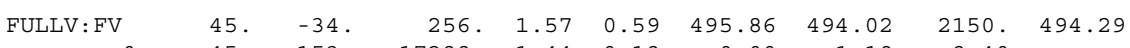

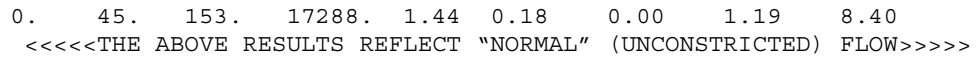

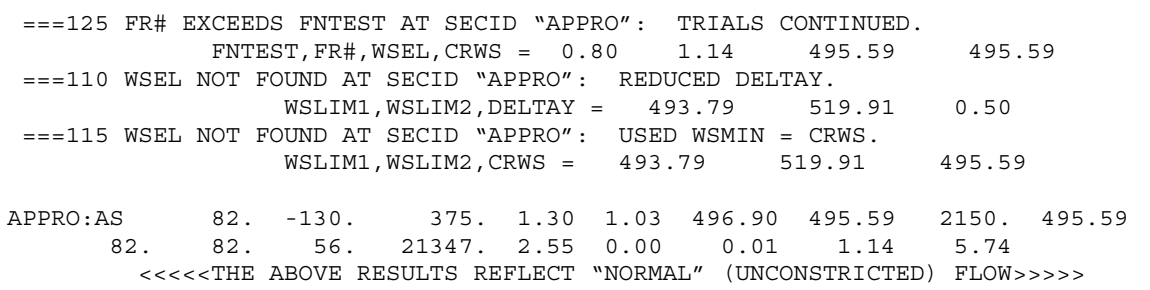 \\ $==255$ ATTEMPTING FLOW CLASS 3 (6) SOLUTION. \\ WS $3 N$, LSEL $=494.29 \quad 494.20$ \\ X $<<<$ RESULTS REFLECTING THE CONSTRICTED FLOW FOLLOW >>>>

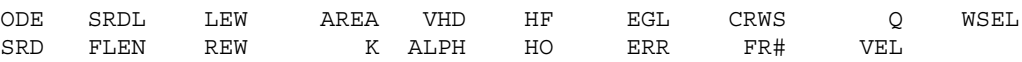


WSPRO OUTPUT FILE (continued)

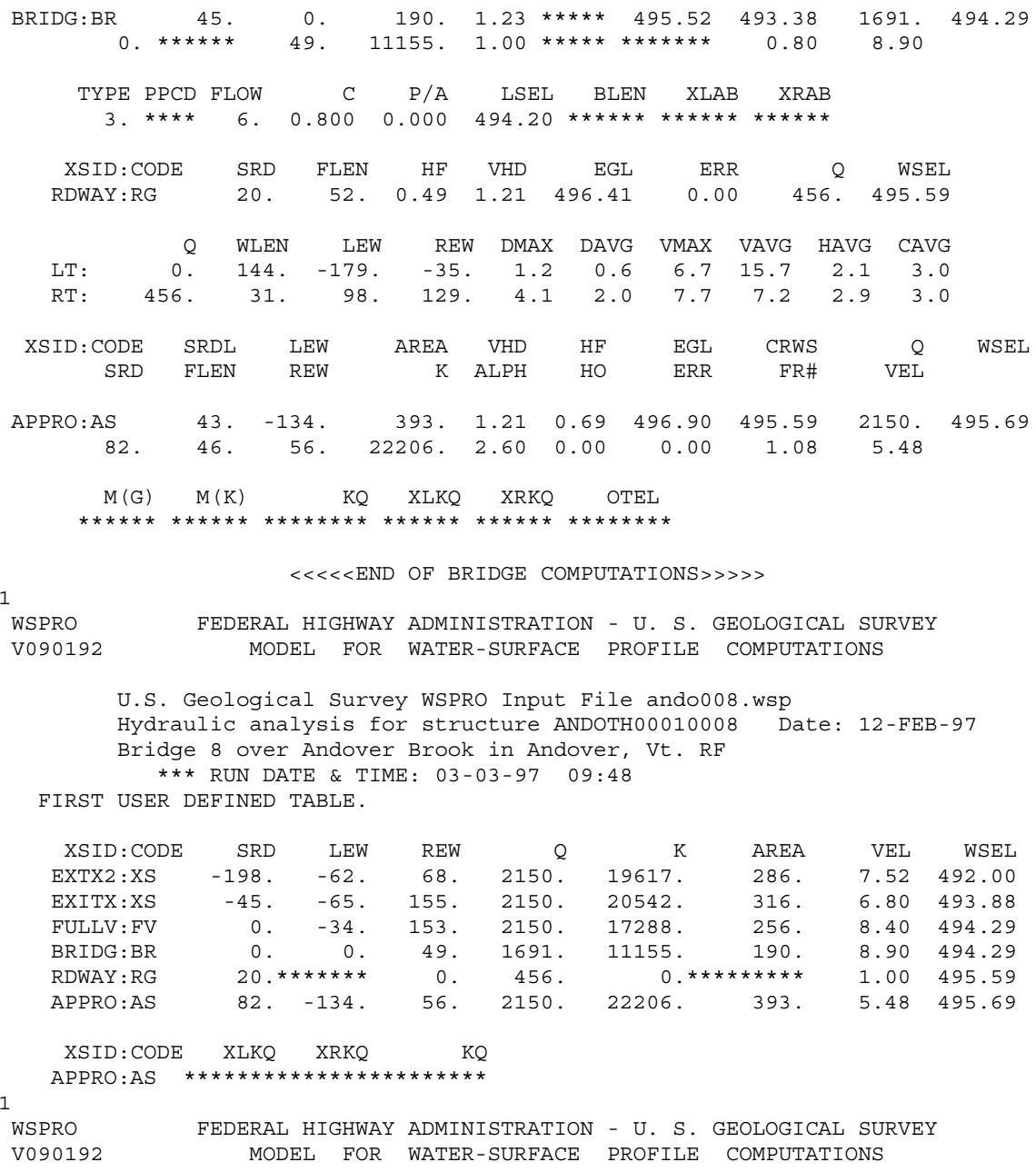


WSPRO OUTPUT FILE (continued)

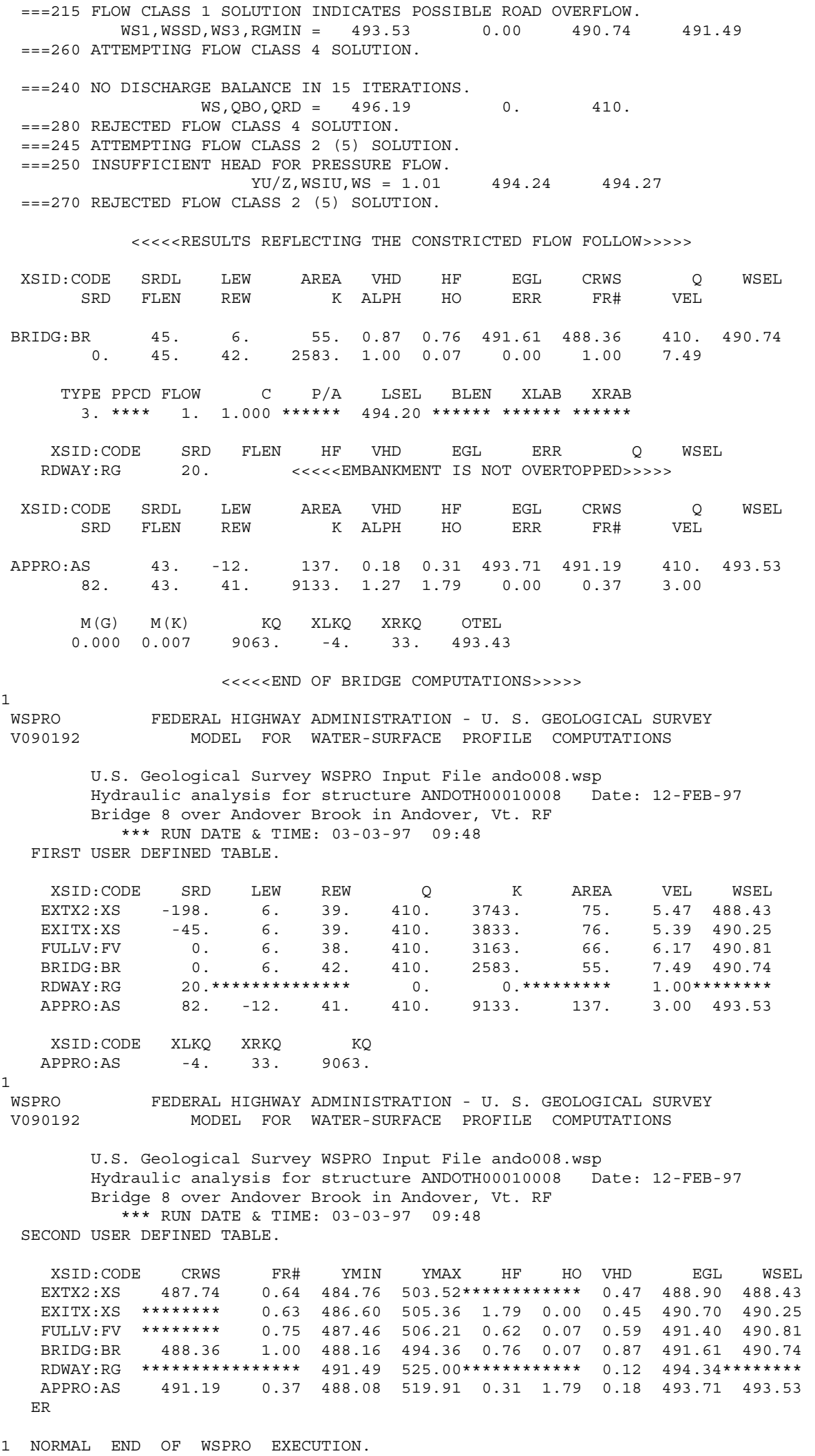




\section{APPENDIX C:}

\section{BED-MATERIAL PARTICLE-SIZE DISTRIBUTION}




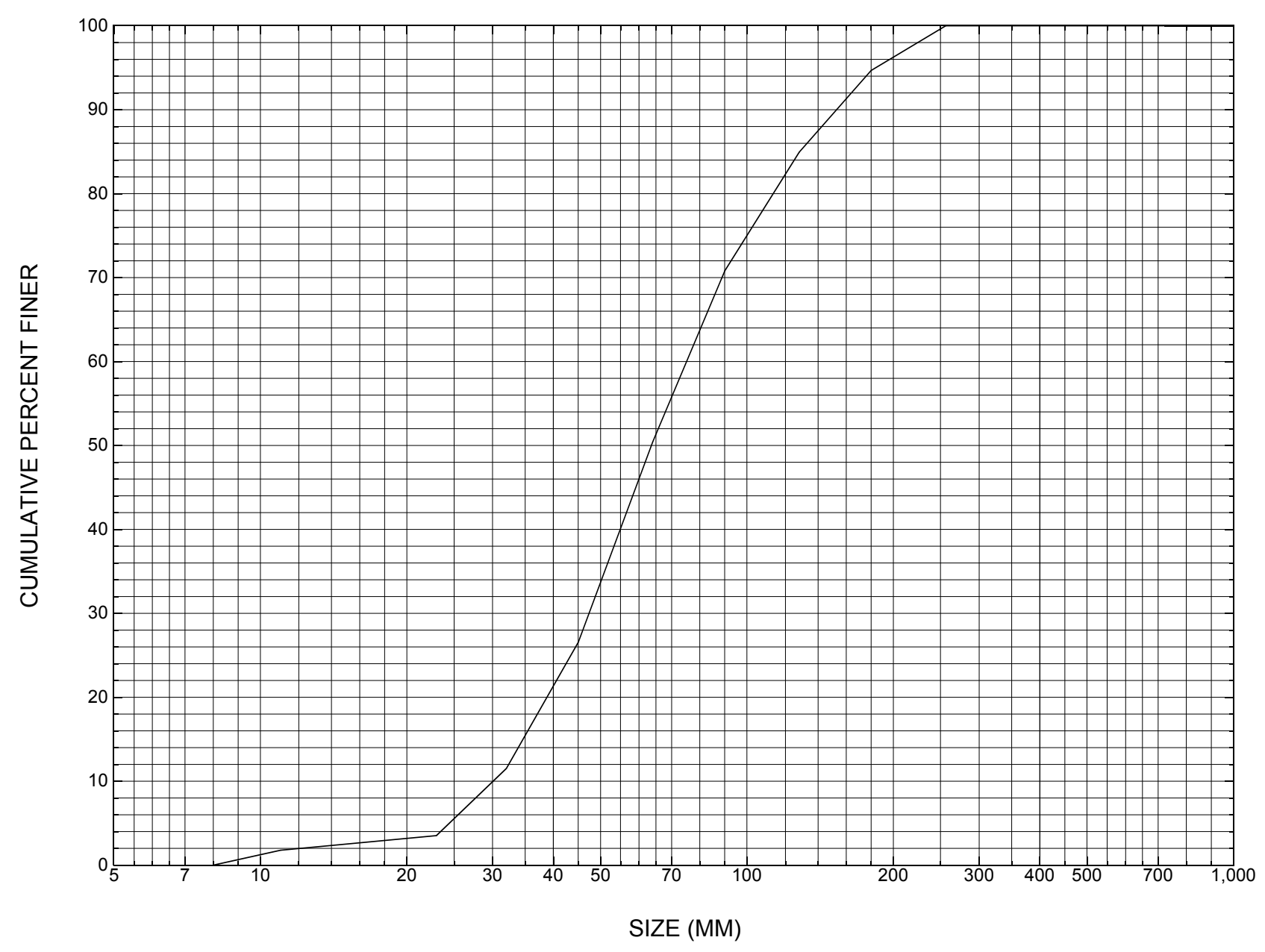

Appendix C. Bed material particle-size distribution for a pebble count in the channel approach of structure ANDOTH00010008, in Andover, Vermont. 


\section{APPENDIX D: \\ HISTORICAL DATA FORM}




\section{Structure Number ANDOTH00010008}

\section{General Location Descriptive}

Data collected by (First Initial, Full last name) $\mathbf{M}$. IVANOFF

Date $(M M / D D / Y Y) \_\mathbf{0 3} / \underline{\mathbf{2 8}} / \underline{\mathbf{9 5}}$

Highway District Number (I - 2; nn) $\mathbf{0 2}$

Town (FIPS place code; I - 4; nnnnn) $\mathbf{0 1 3 0 0}$

Waterway (I - 6) ANDOVER BRANCH

Route Number TH01

Topographic Map Andover

Latitude (I - 16; nnnn.n) 43169
County (FIPS county code; I - 3; nnn)

Mile marker (I - 11; nnn.nnn) $\mathbf{0 0 3 7 1 0}$

Road Name (I - 7): -

Vicinity (I - 9) $\mathbf{3 . 0}$ MI N JCT. VT.11

Hydrologic Unit Code: $\mathbf{0 1 0 8 0 1 0 7}$

Longitude (i - 17; nnnnn.n) $\mathbf{7 2 4 2 5}$

\section{Select Federal Inventory Codes}

FHWA Structure Number (I - 8) $\mathbf{2 0 0 1 3 2 0 0 0 8 1 4 0 1}$

Maintenance responsibility $(I-21 ; n n) \_$03 $\quad$ Maximum span length $(I-48 ; n n n n) \underline{\mathbf{0 0 5 1}}$

Year built (I - 27; YYYY) 1993

Structure length (I - 49; nnnnnn) $\underline{000054}$

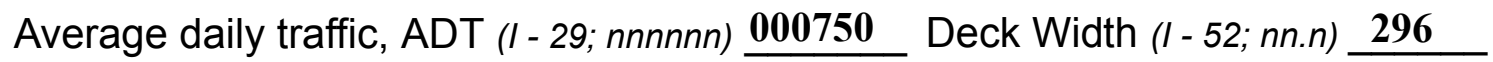

Year of ADT (I - 30; YY) $\mathbf{9 1}$

Channel \& Protection $(I-61 ; n) \mathbf{8}$

Opening skew to Roadway $(I-34 ; n n) \quad \mathbf{3 0}$

Waterway adequacy $(I-71 ; n) \underline{6}$

Operational status $(I-41 ; X)$ A

Underwater Inspection Frequency $(I-92 B ; X Y Y) \_\mathbf{N}$

Structure type (I - 43; nnn) $\mathbf{3 0 2}$

Year Reconstructed (I - 106) $\mathbf{0 0 0 0}$

Approach span structure type $(I-44 ; n n n) \quad \mathbf{0 0 0}$

Clear span (nnn.n ft) $\mathbf{4 2}$

Number of spans (I - 45; nnn) $\mathbf{0 0 1}$

Vertical clearance from streambed (nnn.n ft) $\underline{\mathbf{6 . 0}}$

Number of approach spans (I - 46; nnnn) $\underline{\mathbf{0 0 0 0}}$ Waterway of full opening $\left(n n n . n \mathrm{ft}^{2}\right) \underline{\mathbf{2 0 0}}$

Comments:

The structural inspection report of 8/3/94 indicates the structure is a single span, steel stringer type bridge with an asphalt road surface. The bridge is part of the Federal Aid System listed under the route number, FAS 132. Both abutments are well protected with stone fill. The waterway has a moderate turn just upstream. The stream bed consists of stone and gravel with a few random boulders. 


\section{Bridge Hydrologic Data}

Is there hydrologic data available? $\underline{\mathbf{Y}}$ if No, type ctrl- $h \quad$ VTAOT Drainage area $\left(m i^{2}\right): \underline{\mathbf{5 . 3}}$

Terrain character: Rolling hills, mountainous

Stream character \& type: Straight

Streambed material: gravel and cobbles

Discharge Data (cfs): $\quad \mathrm{Q}_{2.33} \mathbf{3 5 0}$

$\mathrm{Q}_{50} \mathbf{1 2 0 0}$

$\mathrm{Q}_{10} \frac{\mathbf{7 5 0}}{\mathbf{1 4 5 0}}$

$\mathrm{Q}_{25}$

$\mathrm{Q}_{500}$

Record flood date ( $M M / D D / Y Y)$ :

Water surface elevation (ft):

Estimated Discharge (cfs): $\underline{\mathbf{1 0 0 0}}$ Velocity at Q $\underline{\mathbf{2 5}}$ (ft/s): $\underline{\mathbf{6 . 8}}$

Ice conditions (Heavy, Moderate, Light) : slight Debris (Heavy, Moderate, Light): slight

The stage increases to maximum highwater elevation (Rapidly, Not rapidly): rapidly

The stream response is (Flashy, Not flashy): flashy

Describe any significant site conditions upstream or downstream that may influence the stream's

stage: According to the VTAOT files:

Not affected by downstream conditions. Estimated scour of $\mathbf{4}$ feet calculated at the southerly

abutment (right abutment), live bed scour with abutments set at edge of channel.

Watershed storage area (in percent): 1

The watershed storage area is: $\mathbf{2}$ (1-mainly at the headwaters; 2- uniformly distributed; 3-immediatly upstream oi the site)

Water Surface Elevation Estimates for Existing Structure:

\begin{tabular}{|l|l|c|c|l|l|}
\hline Peak discharge frequency & $Q_{2.33}$ & $Q_{10}$ & $Q_{25}$ & $Q_{50}$ & $Q_{100}$ \\
Water surface elevation $(f t))$ & $\mathbf{4 9 1 . 8}$ & $\mathbf{4 9 4 . 0}$ & $\mathbf{4 9 4 . 4}$ & $\mathbf{4 9 4 . 9}$ & $\mathbf{4 9 5 . 4}$ \\
Velocity $(\mathrm{ft} / \mathrm{sec})$ & $\mathbf{7 . 2}$ & $\mathbf{8 . 4}$ & $\mathbf{9 . 2}$ & $\mathbf{7 . 5}$ & $\mathbf{8 . 1}$ \\
\hline
\end{tabular}

Long term stream bed changes: -

Is the roadway overtopped below the $\mathrm{Q}_{100}$ ? (Yes, No, Unknown): $\mathbf{Y} \quad$ Frequency: $\mathbf{Q} 4^{*}$

Relief Elevation $(f t): \underline{493.0}$ Discharge over roadway at $\mathrm{Q}_{100}\left(f^{3} / \mathrm{sec}\right)$ : -

Are there other structures nearby? (Yes, No, Unknown): Y If No or Unknown, type ctrl-n os Upstream distance (miles): 2000' Town: ANDOVER Year Built: Highway No. : TH0001 Structure No. : 005 Structure Type: Clear span (ft): $\underline{19}$ Clear Height $(f t): \underline{\mathbf{8}}$ Full Waterway $\left(f t^{2}\right): \underline{-}$ 
Downstream distance (miles): 3 3500' Town: ANDOVER Year Built:

Highway No. : TH023 Structure No. : $\mathbf{0 2 5}$ Structure Type:

Clear span (ft): 23 Clear Height $(f t): \underline{12}$ Full Waterway $\left(f t^{2}\right)$ :

Comments:

* Flow jumps bank at right abutment, then flows along side of highway until it overtops highway at about 300 feet from the bridge.

\section{USGS Watershed Data}

Watershed Hydrographic Data

Drainage area $(D A)$

5.30 $\mathrm{mi}^{2}$ Lake and pond area 0.01 $\mathrm{mi}^{2}$

Watershed storage (ST) 0.1

Bridge site elevation 1180 $\mathrm{ft}$ $\%$

Main channel length 3.616 mi

$10 \%$ channel length elevation 1320 $\mathrm{ft} \quad 85 \%$ channel length elevation $\mathrm{ft}$

Main channel slope $(S)$

(S) 331.85 $\mathrm{ft} / \mathrm{mi}$

Watershed Precipitation Data

Average site precipitation in Average headwater precipitation in

Maximum 2yr-24hr precipitation event $(124,2)$ in

Average seasonal snowfall (Sn) $\mathrm{ft}$ 


\section{Bridge Plan Data}

Are plans available? $\underline{Y}$ If no, type ctrl-n pl Date issued for construction (MM/YYYY): $\underline{\mathbf{1 0}}$ / 1991 Project Number BHS 0132(5)

Minimum channel bed elevation: $\underline{\mathbf{4 8 8 . 0}}$

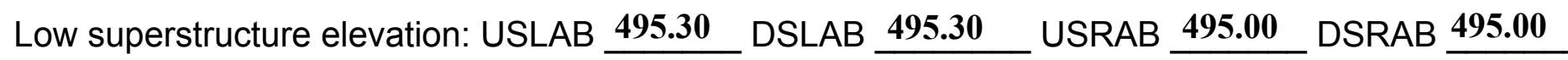

Benchmark location description:

Roadway to the temporary bridge is shown over the area where BM's were originally established so they probably don't exist now. BM\#1 is a spike in trunk of an 18" ash tree about 243 feet left bankward on the roadway from the left abutment and about 20 feet perpendicular from the roadway center line in a downstream direction, elevation 500.0.

Reference Point (MSL, Arbitrary, Other): Arbitrary _ Datum (NAD27, NAD83, Other): Arbitrary Foundation Type: 1 (1-Spreadfooting; 2-Pile; 3- Gravity; 4-Unknown)

If 1: Footing Thickness $\mathbf{2 . 5} \quad$ Footing bottom elevation: $\underline{\mathbf{4 8 9 . 0}}$

If 2: Pile Type:___ (1-Wood; 2-Steel or metal; 3-Concrete) Approximate pile driven length:

If 3: Footing bottom elevation:

Is boring information available? $\mathbf{N}$ If no, type ctrl- $n$ bi Number of borings taken: _-

Foundation Material Type: $\mathbf{3}$ (1-regolith, 2-bedrock, 3-unknown)

Briefly describe material at foundation bottom elevation or around piles:

NO FOUNDATION MATERIAL INFORMATION.

Comments:

*The base of footing elevations are left: 489.0 and right: 487.8 . The plans show only rehabilitation construction, which seems to leave the cross sections pending, as a channel base line for the measuring of section location from the bridge is shown on the plans but, sections are not attached (yet). Flows(Q), drainage area, and outlet velocity at $Q 25$ are printed on plans. 


\section{Cross-sectional Data}

Is cross-sectional data available? $\mathbf{N}$ If no, type ctrl-n xs

Source (FEMA, VTAOT, Other)? -

Comments: -

\begin{tabular}{|l|l|l|l|l|l|l|l|l|l|l|l|}
\hline Station & - & - & - & - & - & - & - & - & - & - & - \\
\hline Feature & - & - & - & - & - & - & - & - & - & - & - \\
\hline $\begin{array}{l}\text { Low cord } \\
\text { elevation }\end{array}$ & - & - & - & - & - & - & - & - & - & - & - \\
\hline $\begin{array}{l}\text { Bed } \\
\text { elevation }\end{array}$ & - & - & - & - & - & - & - & - & - & - & - \\
\hline $\begin{array}{l}\text { Low cord to } \\
\text { bed length }\end{array}$ & - & - & - & - & - & - & - & - & - & - & - \\
\hline Station & - & - & - & - & - & - & - & - & - & - & - \\
\hline Feature & - & - & - & - & - & - & - & - & - & - & - \\
\hline $\begin{array}{l}\text { Low cord } \\
\text { elevation }\end{array}$ & - & - & - & - & - & - & - & - & - & - & - \\
\hline $\begin{array}{l}\text { Bed } \\
\text { elevation }\end{array}$ & - & - & - & - & - & - & - & - & - & - & - \\
\hline $\begin{array}{l}\text { Low cord to } \\
\text { bed length }\end{array}$ & - & - & - & - & - & - & - & - & - & - & - \\
\hline
\end{tabular}

Source (FEMA, VTAOT, Other)?

Comments: -

\begin{tabular}{|l|l|l|l|l|l|l|l|l|l|l|l|}
\hline Station & - & - & - & - & - & - & - & - & - & - & - \\
\hline Feature & - & - & - & - & - & - & - & - & - & - & - \\
\hline $\begin{array}{l}\text { Low cord } \\
\text { elevation }\end{array}$ & - & - & - & - & - & - & - & - & - & - & - \\
\hline $\begin{array}{l}\text { Bed } \\
\text { elevation }\end{array}$ & - & - & - & - & - & - & - & - & - & - & - \\
\hline $\begin{array}{l}\text { Low cord to } \\
\text { bed length }\end{array}$ & - & - & - & - & - & - & - & - & - & - & - \\
\hline Station & - & - & - & - & - & - & - & - & - & - & - \\
\hline Feature & - & - & - & - & - & - & - & - & - & - & - \\
\hline $\begin{array}{l}\text { Low cord } \\
\text { elevation }\end{array}$ & - & - & - & - & - & - & - & - & - & - & - \\
\hline $\begin{array}{l}\text { Bed } \\
\text { elevation }\end{array}$ & - & - & - & - & - & - & - & - & - & - & - \\
\hline $\begin{array}{l}\text { Low cord to } \\
\text { bed length }\end{array}$ & - & - & - & - & - & - & - & - & - & - & - \\
\hline
\end{tabular}




\section{APPENDIX E: \\ LEVEL I DATA FORM}


U. S. Geological Survey

Bridge Field Data Collection and Processing Form

Qa/Qc Check by: $\mathbf{R B}$ Date: $09 / \mathbf{2 4 / 9 6}$

\section{Structure Number}

ANDOTH00010008

Computerized by: $\underline{\mathbf{R B}}$ Date: $09 / 25 / 96$

Reviewd by: $\quad$ RF Date: $\underline{\mathbf{0 2} / \mathbf{2 1} / \mathbf{9 7}}$

\section{A. General Location Descriptive}

1. Data collected by (First Initial, Full last name) E. WILD

2. Highway District Number $\mathbf{0 2}$

County 027 WINDSOR

Waterway (l - 6) ANDOVER BRANCH

Route Number TH01

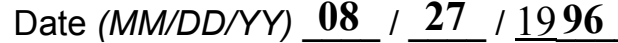

Descriptive comments:

Located 3.0 miles north of the junction with VT 11.

Mile marker $\mathbf{0 0 3 7 1 0}$

Town 01300 ANDOVER

Road Name -

Hydrologic Unit Code: $\mathbf{0 1 0 8 0 1 0 7}$

\section{B. Bridge Deck Observations}
4. Surface cover... LBUS 4
RBUS 6
LBDS 6
RBDS 6
Overall 6

(2b us, ds,lb,rb: 1- Urban; 2- Suburban; 3- Row crops; 4- Pasture; 5- Shrub- and brushland; 6- Forest; 7- Wetland)
5. Ambient water surface... US $\underline{2}$
UB 2
DS $\underline{2}$
(1- pool; 2- riffle)

6. Bridge structure type 1 (1- single span; 2- multiple span; 3- single arch; 4- multiple arch; 5-cylindrical culvert; 6- box culvert; or 7- other)
7. Bridge length $\mathbf{5 4}$
(feet)
Span length $\underline{\mathbf{5 1}}$
(feet)
Bridge width 29.6 (feet)

\section{Road approach to bridge:}
8. LB 1 RB 1
( 0 even, 1- lower, 2- higher)
9. $\mathrm{LB}$ RB 1
(1-Paved, 2- Not paved)

10. Embankment slope (run / rise in feet / foot):

US left

US right

\begin{tabular}{|c|c|c|c|c|}
\hline & \multicolumn{2}{|c|}{ Protection } & \multirow{2}{*}{ 13.Erosion } & \multirow{2}{*}{ 14.Severity } \\
\hline & 11. Type & 12.Cond. & & \\
\hline LBUS & $\mathbf{0}$ & - & $\mathbf{0}$ & - \\
\hline RBUS & $\mathbf{0}$ & - & $\mathbf{0}$ & - \\
\hline RBDS & $\mathbf{0}$ & - & $\mathbf{0}$ & - \\
\hline LBDS & $\mathbf{0}$ & - & $\mathbf{0}$ & - \\
\hline
\end{tabular}

Bank protection types: 0 - none; 1- $<12$ inches;

2- < 36 inches; 3- < 48 inches;

4- < 60 inches; 5- wall / artificial levee

Bank protection conditions: 1- good; 2- slumped;

3- eroded; 4- failed

Erosion: 0 - none; 1- channel erosion; 2-

road wash; 3- both; 4- other

Erosion Severity: 0 - none; 1- slight; 2- moderate;

\section{Channel approach to bridge (BF):}

15. Angle of approach: $\mathbf{5}$

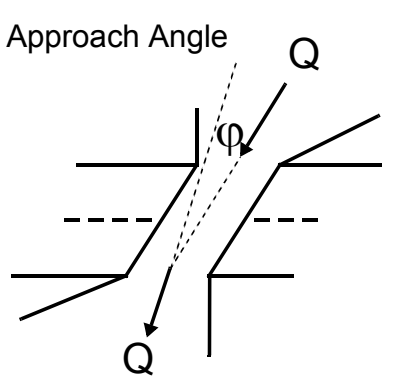

17. Channel impact zone 1 :

Where? RB (LB, RB)

Range? 100 feet US

Channel impact zone 2 :

Where? LB (LB, RB)

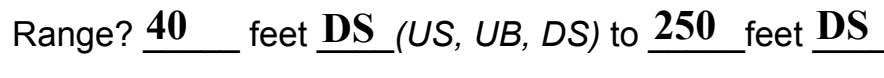

Impact Severity: 0- none to very slight; 1- Slight; 2- Moderate; 3- Severe
16. Bridge skew: 45 Bridge Skew Angle

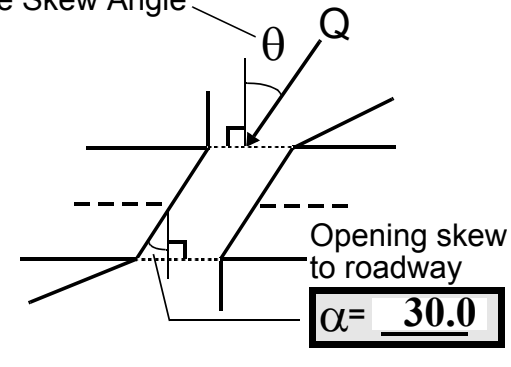

\section{Exist? $\underline{\mathbf{Y}}(\mathrm{Y}$ or $N)$}

Severity 1

(US, UB, DS) to $\underline{67}$ feet $\underline{\mathbf{U S}}$

Exist? $\mathbf{Y}(Y$ or $N)$

Severity $\underline{2}$ 
18. Bridge Type: $\underline{\mathbf{3} / \mathbf{1 a}}$

1a- Vertical abutments with wingwalls

1 b- Vertical abutments without wingwalls

2- Vertical abutments and wingwalls, sloping embankment Wingwalls perpendicular to abut. face

3- Spill through abutments

4- Sloping embankment, vertical wingwalls and abutments

Wingwall angle less than $90^{\circ}$.

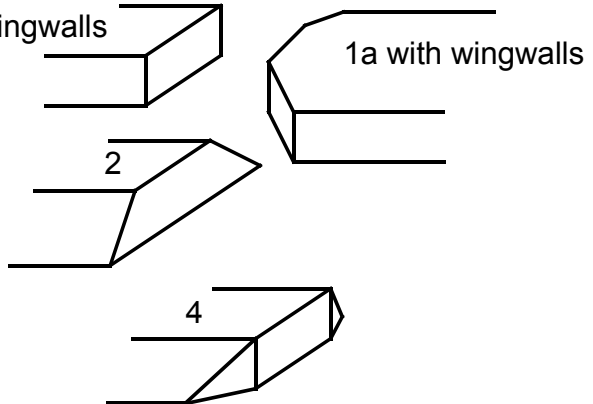

19. Bridge Deck Comments (surface cover variations, measured bridge and span lengths, bridge type variations, approach overflow width, etc.)

4. Surface cover is forest except for 1 bridge length US and DS on both the right and left banks where it is grass. A small brick house is on the DS left bank.

8. and 9. The left and right road approaches are paved until the road dip (where the hills start). Beyond the dip in the road, the road has recently been chip sealed and there is loose rock on the pavement.

7. Values are from the VTAOT files. Measured bridge length is $54 \mathrm{ft}$., span length is $50 \mathrm{ft}$. and bridge width is 33 ft.

\section{Upstream Channel Assessment}

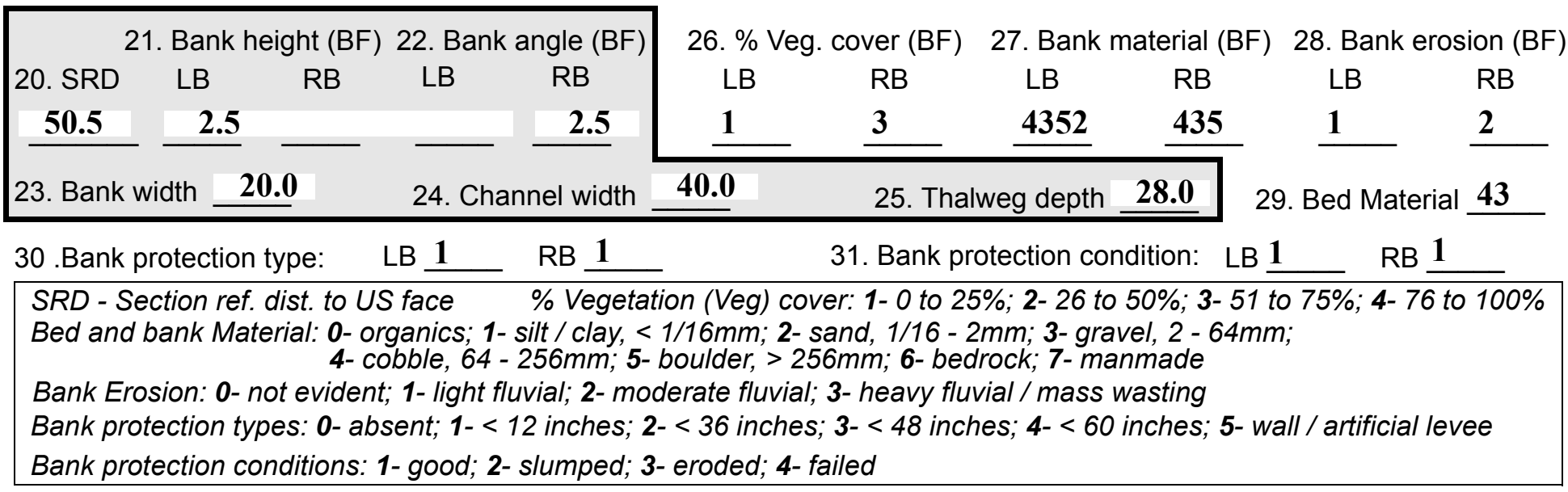

32. Comments (bank material variation, minor inflows, protection extent, etc.):

26. With the exception of grass on either bank, there is no other vegetation from the US bridge face to one bridge length US. Beyond this point, the banks are tree covered.

30. On the right bank the protection extends from the US bridge face to $47 \mathrm{ft}$. US. The left bank protection is type 1 from $65 \mathrm{ft}$. US to $40 \mathrm{ft}$. US and type 3 from $89 \mathrm{ft}$. US to $65 \mathrm{ft}$. US. 
33.Point/Side bar present? $\mathbf{Y}$

$(Y$ or $N$. if $N$ type ctrl-n pb)34. Mid-bar distance: 26

35. Mid-bar width: 11

36. Point bar extent: 69 feet US

(US, UB) to 26 feet $\underline{\text { DS }}$

(US, UB, DS) positioned $\mathbf{0}$ $\%$ LB to 80 $\%$ RB

37. Material: $\mathbf{4 3}$

38. Point or side bar comments (Circle Point or Side; Note additional bars, material variation, status, etc.):

Additional alternating side bars are US. From $153 \mathrm{ft}$. US to $101 \mathrm{ft}$. US, there is a gravel and cobble bar positioned $40 \%$ LB to $100 \%$ RB with mid-bar distance at $136 \mathrm{ft}$. US and a width of $11.5 \mathrm{ft}$. From $230 \mathrm{ft}$. US to 167 ft. US, there is another gravel and cobble bar positioned $0 \% \mathrm{LB}$ to $50 \% \mathrm{RB}$ with a mid-bar distance at $200 \mathrm{ft}$. US.
39. Is a cut-bank present? Y
( $Y$ or if $N$ type $c$ trl-n $c b)$
40. Where? $\mathbf{R B}$ (LB or $R B)$

41. Mid-bank distance: $\mathbf{7 5}$

42. Cut bank extent: 95 eet $\underline{\mathbf{U S}}$ (US, UB, DS)

43. Bank damage: 1

(1- eroded and/or creep; 2- slip failure; 3- block failure)

44. Cut bank comments (eg. additional cut banks, protection condition, etc.):

$-$

45. Is channel scour present? $\mathbf{N}$ ( $Y$ or if $N$ type ctrl-n cs)

47. Scour dimensions: Length Width -

Depth : -

46. Mid-scour distance: -

48. Scour comments (eg. additional scour areas, local scouring process, etc.):

NO CHANNEL SCOUR

49. Are there major confluences? $\mathbf{N}$

51. Confluence 1: Distance Confluence 2: Distance 52. Enters on Enters on 54. Confluence comments (eg. confluence name):

NO MAJOR CONFLUENCES
( $Y$ or if $N$ type ctrl-n $m c$ ) ( $L B$ or $R B)$ (LB or $R B)$
50. How many? -

53. Type(1-perennial; 2- ephemeral)

Type (1-perennial; 2-ephemeral)

NO MAJOR CONFLUENCES

\section{Under Bridge Channel Assessment}

55. Channel restraint (BF)? LB 2

56. Height (BF)
LB RB
$\mathbf{1 8 . 5}-$
58. Bank width (BF) -

59. Channel width $(\mathrm{Amb})$

(1- natural bank; 2- abutment; 3- artificial levee)

Bed and bank Material: 0- organics; 1- silt / clay, < 1/16mm; 2- sand, 1/16 - 2mm; 3- gravel, 2 - 64mm; 4- cobble, 64 - 256mm; 5- boulder, > 256mm; 6- bedrock; 7- manmade

Bank Erosion: 0- not evident; 1- light fluvial; 2- moderate fluvial; 3- heavy fluvial / mass wasting

64. Comments (bank material variation, minor inflows, protection extent, etc.):

34

The abutment protection (dumped stone) acts like a spill through, but at bank full, the water level is even with the bottom of the abutments. 
65. Debris and Ice Is there debris accumulation?

$(Y$ or $N)$ 66. Where? $\underline{Y}$

(1- Upstream; 2- At bridge; 3- Both)

67. Debris Potential 1 (1-Low; 2-Moderate; 3- High)

68. Capture Efficiency 2

(1-Low; 2- Moderate; 3- High)

69. Is there evidence of ice build-up? 2

Ice Blockage Potential $\underline{\mathbf{N}}$

(1- Low; 2- Moderate; 3- High)

70. Debris and Ice Comments:

2

69. There is no evidence of ice build up but, the blockage potential is moderate because of the low clearance under the bridge.

66. There is debris both US and DS within one bridge length.

\begin{tabular}{|l|c|c|c|c|c|c|c|c|}
\hline Abutments & $\begin{array}{c}\text { 71. Attack } \\
\angle \text { (BF) }\end{array}$ & $\begin{array}{c}\text { 72. Slope } \angle \\
\text { (Qmax) }\end{array}$ & $\begin{array}{c}\text { 73. Toe } \\
\text { loc. (BF) }\end{array}$ & $\begin{array}{c}\text { 74. Scour } \\
\text { Condition }\end{array}$ & $\begin{array}{c}75 . \text { Scour } \\
\text { depth }\end{array}$ & $\begin{array}{c}\text { 76. Exposure } \\
\text { depth }\end{array}$ & 77. Material & 78. Length \\
\hline LABUT & & $\mathbf{0}$ & $\mathbf{9 0}$ & $\mathbf{0}$ & $\mathbf{0}$ & - & - & $\mathbf{9 0 . 0}$ \\
\hline RABUT & $\mathbf{1}$ & $\mathbf{1 5}$ & $\mathbf{9 0}$ & & & $\mathbf{0}$ & $\mathbf{0}$ & $\mathbf{4 2 . 5}$ \\
\hline
\end{tabular}

Pushed: $L B$ or RB

Toe Location (Loc.): 0- even, 1- set back, 2- protrudes

Scour cond.: 0- not evident; 1- evident (comment); 2- footing exposed; 3-undermined footing; 4- piling exposed; 5- settled; 6- failed

Materials: 1- Concrete; 2- Stone masonry or drywall; 3- steel or metal; 4- wood

79. Abutment comments (eg. undermined penetration, unusual scour processes, debris, etc.):

-

1

72. The abutment protection slope is $\mathbf{4 0}$ degrees in front of the left and right abutments.

80. Wingwalls:

Exist? Material? Scour Scour Exposure Angle? Length? Condition? depth? depth?

USLWW:

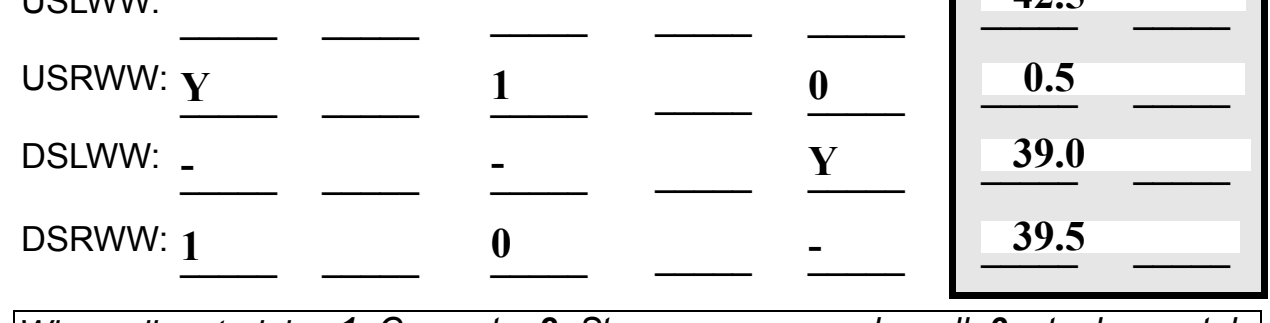

Wingwall materials: 1- Concrete; 2- Stone masonry or drywall; 3- steel or metal; 4- wood

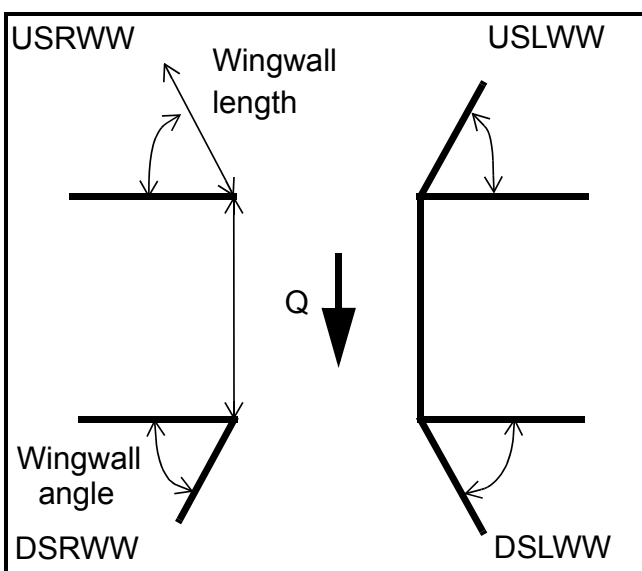

82. Bank / Bridge Protection:

\begin{tabular}{|l|l|l|l|l|l|l|l|c|}
\hline Location & USLWW & USRWW & LABUT & RABUT & LB & RB & DSLWW & DSRWW \\
\hline Type & - & $\mathbf{0}$ & $\mathbf{Y}$ & - & - & - & $\mathbf{1}$ & $\mathbf{1}$ \\
\hline Condition & $\mathbf{Y}$ & - & $\mathbf{1}$ & - & - & - & $\mathbf{1}$ & $\mathbf{1}$ \\
\hline Extent & $\mathbf{1}$ & - & $\mathbf{0}$ & $\mathbf{0}$ & $\mathbf{0}$ & $\mathbf{2}$ & $\mathbf{2}$ & - \\
\hline
\end{tabular}

Bank / Bridge protection types: 0- absent; 1- < 12 inches; 2- < 36 inches; 3- < 48 inches; 4- < 60 inches; 
83. Wingwall and protection comments (eg. undermined penetration, unusual scour processes, etc.):

$-$

$-$

$-$

$-$

$-$

0

$-$

0

0

\section{Piers:}

84. Are there piers? $\mathbf{8 0 .}$ ( $Y$ or if $N$ type ctrl-n pr)

\begin{tabular}{|l|c|c|c|c|c|c|c|}
\hline $\begin{array}{l}85 . \\
\text { Pier no. }\end{array}$ & \multicolumn{3}{|c|}{ width (w) feet } & \multicolumn{3}{|c|}{ elevation (e) feet } \\
\cline { 2 - 8 } & w1 & w2 & w3 & e@w1 & e@w2 & e@w3 \\
\hline Pier 1 & & & & $\mathbf{3 0 . 0}$ & $\mathbf{1 2 . 5}$ & $\mathbf{6 0 . 0}$ \\
\hline Pier 2 & $\mathbf{8 . 0}$ & $\mathbf{6 . 0}$ & & $\mathbf{6 0 . 0}$ & $\mathbf{3 0 . 0}$ & $\mathbf{1 0 . 0}$ \\
\hline Pier 3 & - & - & - & - & - & - \\
\hline Pier 4 & - & - & - & - & - & - \\
\hline
\end{tabular}

\begin{tabular}{|l|l|l|l|l|}
\hline Level 1 Pier Descr. & \multicolumn{1}{|c|}{1} & \multicolumn{1}{|c|}{2} & 3 & 4 \\
\hline 86. Location (BF) & The & have & & - \\
\hline 87. Type & wing & grass & & - \\
\hline 88. Material & walls & and & & - \\
\hline 89. Shape & are & soft & & - \\
\hline 90. Inclined? & even & soil & & - \\
\hline 91. Attack $\angle$ (BF) & with & in & & - \\
\hline 92. Pushed & the & front & & - \\
\hline 93. Length (feet) & - & - & - & - \\
\hline 94. \# of piles & top & of & & - \\
\hline 95. Cross-members & of & them & N & - \\
\hline 96. Scour Condition & the & - & - & - \\
\hline 97. Scour depth & bank & & - & - \\
\hline 98. Exposure depth & sand & & - & - \\
\hline
\end{tabular}

LFP, LTB, LB, MCL, MCM, MCR, RB, RTB, RFP

1- Solid pier, 2-column, 3- bent

1-Wood; 2-concrete; 3- metal; 4- stone

1- Round; 2- Square; 3- Pointed

Y-yes; $N$ - no

$L B$ or $R B$

0- none; 1- laterals; 2- diagonals; 3- both

0- not evident; 1- evident (comment);

2- footing exposed; 3- piling exposed;

4- undermined footing; 5- settled; 6- failed 
99. Pier comments (eg. undermined penetration, protection and protection extent, unusual scour processes, etc.):

-
-
-
-
-
-
-
-
-
-

100.

\section{E. Downstream Channel Assessment}

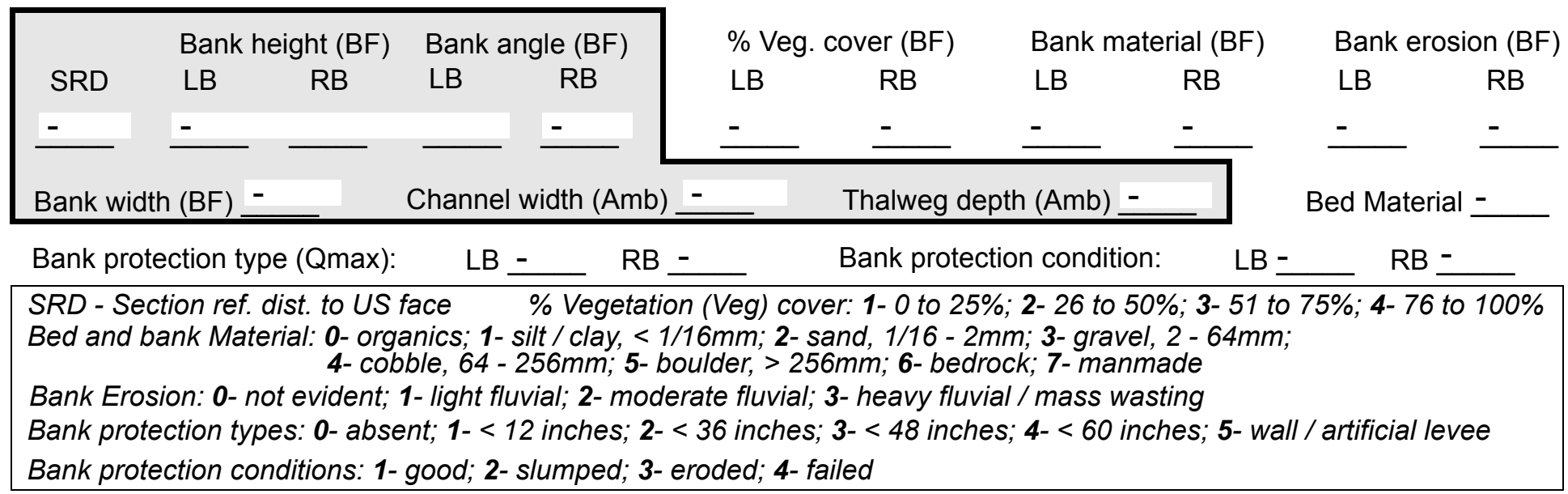

Comments (eg. bank material variation, minor inflows, protection extent, etc.):

$-$

$-$

$-$

$-$

$-$

$-$

$-$

$-$

-

-

$-$

-

NO PIERS

101. Is a drop structure present? ( $Y$ or $N$, if $N$ type ctrl-n ds)

102. Distance: - feet

103. Drop: -_ feet 104. Structure material: (1- steel sheet pile; 2- wood pile; 3- concrete; 4- other)

105. Drop structure comments (eg. downstream scour depth): 
Point bar extent: 1 feet 1 (US, UB, DS) to $\underline{\mathbf{4 3 5}}$ feet $\underline{\mathbf{0}}$ (US, UB, DS) positioned $\underline{\mathbf{0}}$ $\%$ LB to $\% \mathrm{RB}$

Material:

Point or side bar comments (Circle Point or Side; note additional bars, material variation, status, etc.):

There is only grass as vegetation along the banks from the DS bridge face to 1 bridge length DS. On the left bank, about $45 \mathrm{ft}$. DS, there are boulders along the bank that at one time were protection, but have since failed.

The bed drops about $1 \mathrm{ft}$. at $43 \mathrm{ft}$. DS where there is a cluster of boulders in the channel.

Is a cut-bank present?

Cut bank extent: feet (Y or if $N$ type ctrl-n cb)

Where? (LB or $R B)$

Mid-bank distance: (US, UB, DS) to feet (US, UB, DS)

Bank damage:

Cut bank comments (eg. additional cut banks, protection condition, etc.):

$\mathbf{N}$

Is channel scour present? ( $Y$ or if $N$ type ctrl-n cs)

Mid-scour distance: $\mathbf{N O}$

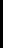

Are there major confluences?

Confluence 1: Distance $\underline{\mathbf{Y}}$ ( $Y$ or if $N$ type ctrl-n $m c)$

Enters on $\underline{\mathbf{1 6 7}}$ (LB or $R B)$
Enters on $\underline{\text { DS }} \quad(L B$ or $R B)$

DS

20

\section{F. Geomorphic Channel Assessment} cour comments (eg. additional scour areas, local scouring process, etc.):

\section{Stage of reach evolution}

1- Constructed

2- Stable

3- Aggraded

4- Degraded

6- Vertically and laterally unstable 
108. Evolution comments (Channel evolution not considering bridge effects; See HEC-20, Figure 1 for geomorphic descriptors):

435

Refer to the US assessment for the point bar closest to the bridge.

Y

LB

53

45

US

57

DS

1 


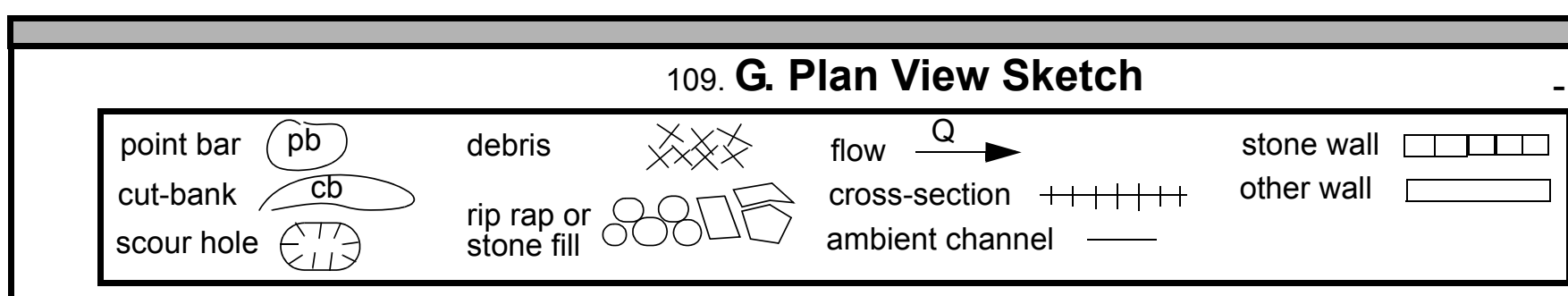


APPENDIX F:

SCOUR COMPUTATIONS 
SCOUR COMPUTATIONS

\begin{tabular}{|c|c|c|c|}
\hline $\begin{array}{ll}\text { Structure Number: ANDOTH00010008 } \\
\text { Road Number: } & \text { THO1 }\end{array}$ & & $\begin{array}{l}\text { Town: } \\
\text { County: }\end{array}$ & $\begin{array}{l}\text { Andover } \\
\text { Windsor }\end{array}$ \\
\hline Stream: Andover Brook & & & \\
\hline Initials RHF & Checked: & SAO & \\
\hline Analysis of contraction scour, live & -bed or $\mathrm{c}$ - & lear wat & \\
\hline $\begin{array}{l}\text { Critical Velocity of Bed Material } \\
\text { VC=11.21*V1^0.1667*D50^0.33 with Ss }\end{array}$ & converted & to Eng] & sh units) \\
\hline (Richardson and others, 1995, p. 28 & eq. 16$)$ & & \\
\hline pproach section & & & \\
\hline Characteristic & $100 \mathrm{yr}$ & $500 \mathrm{yr}$ & other $Q$ \\
\hline Total discharge, cfs & 1450 & 2150 & 410 \\
\hline Main Channel Area, ft2 & 158 & 174 & 114 \\
\hline Left overbank area, ft2 & 90 & 160 & 8 \\
\hline Right overbank area, ft2 & 44 & 59 & 14 \\
\hline Top width main channel, ft & 28 & 28 & 28 \\
\hline Top width L overbank, ft & 111 & 134 & 12 \\
\hline Top width $\mathrm{R}$ overbank, ft & 24 & 29 & 13 \\
\hline D50 of channel, ft & 0.2086 & 0.2086 & 0.2086 \\
\hline D50 left overbank, ft & -- & -- & -- \\
\hline D50 right overbank, ft & -- & -- & -- \\
\hline Y1, average depth, MC, ft & 5.6 & 6.2 & 4.1 \\
\hline Y1, average depth, LOB, ft & 0.8 & 1.2 & 0.7 \\
\hline$y_{1}$, average depth, $R O B, f t$ & 1.8 & 2.0 & 1.1 \\
\hline Total conveyance, approach & 17455 & 22218 & 9124 \\
\hline Conveyance, main channel & 15095 & 17679 & 8785 \\
\hline Conveyance, LOB & 1304 & 2983 & 107 \\
\hline Conveyance, ROB & 1056 & 1556 & 232 \\
\hline Percent discrepancy, conveyance & 0.0000 & 0.0000 & 0.0000 \\
\hline Qm, discharge, MC, cfs & 1254.0 & 1710.8 & 394.8 \\
\hline Q1, discharge, LOB, cfs & 108.3 & 288.7 & 4.8 \\
\hline Qr, discharge, ROB, cfs & 87.7 & 150.6 & 10.4 \\
\hline Vm, mean velocity $\mathrm{MC}$, ft/s & 7.9 & 9.8 & 3.5 \\
\hline VI, mean velocity, LOB, ft/s & 1.2 & 1.8 & 0.6 \\
\hline Vr, mean velocity, $R O B, f t / s$ & 2.0 & 2.6 & 0.7 \\
\hline Vc-m, crit. velocity, MC, ft/s & 8.9 & 9.0 & 8.4 \\
\hline Vc-l, crit. velocity, LOB, ft/s & $\mathrm{ERR}$ & ERR & $\mathrm{ERR}$ \\
\hline Vc-r, crit. velocity, ROB, ft/s & ERR & ERR & ERR \\
\hline Results & & & \\
\hline Live-bed(1) or Clear-Water(0) Contr & action $\mathrm{Sc}$ & our? & \\
\hline Main Channel & 0 & 1 & 0 \\
\hline Left Overbank & $\mathrm{N} / \mathrm{A}$ & $\mathrm{N} / \mathrm{A}$ & $\mathrm{N} / \mathrm{A}$ \\
\hline Right Overbank & $\mathrm{N} / \mathrm{A}$ & $\mathrm{N} / \mathrm{A}$ & $\mathrm{N} / \mathrm{A}$ \\
\hline
\end{tabular}

ARMORING 


$\begin{array}{llll}\text { D90 } & 0.50109 & 0.50109 & 0.50109 \\ \text { D95 } & 0.60281 & 0.60281 & 0.60281 \\ \text { Critical grain size,Dc, ft } & 0.1603 & 0.3368 & 0.3758 \\ \text { Decimal-percent coarser than Dc } & 0.67869 & 0.23914 & 0.19509 \\ \text { Depth to armoring,ft } & 0.23 & 3.21 & 4.65\end{array}$

Live-Bed Contraction Scour

Laursen's Live Bed Contraction Scour

$\mathrm{Y} 2 / \mathrm{Y} 1=(\mathrm{Q} 2 / \mathrm{Q} 1)^{\wedge}(6 / 7) *(\mathrm{~W} 1 / \mathrm{W} 2)^{\wedge}(\mathrm{k} 1)$

ys $=y^{2}-y \_b r i d g e$

(Richardson and others, 1995, p. 30, eq. 17 and 18)

\begin{tabular}{|c|c|c|c|c|c|c|}
\hline & Approach & & & Bridge & & \\
\hline Characteristic & $100 \mathrm{yr}$ & $500 \mathrm{yr}$ & Other Q & $100 \mathrm{yr}$ & $500 \mathrm{yr}$ & Other Q \\
\hline Q1, discharge, cfs & 1450 & 2150 & 410 & 1158 & 1691 & 0 \\
\hline Total conveyance & 17455 & 22218 & 9124 & 12250 & 11127 & 0 \\
\hline Main channel conveyance & 15095 & 17679 & 8785 & 12250 & 11127 & 0 \\
\hline Main channel discharge & 1254 & 1711 & 395 & 1158 & 1691 & ERR \\
\hline Area - main channel, ft2 & 158 & 174 & 114 & 188.6 & 190 & 0 \\
\hline (W1) channel width, ft & 28 & 28 & 28 & 35.25 & 35.51 & 0 \\
\hline (Wp) cumulative pier width, ft & 0 & 0 & 0 & 0 & 0 & 0 \\
\hline W1, adjusted bottom width(ft) & 28 & 28 & 28 & 35.25 & 35.51 & 0 \\
\hline $\mathrm{D} 50, \mathrm{ft}$ & 0.2086 & 0.2086 & 0.2086 & & & \\
\hline w, fall velocity, ft/s (p. 32) & 3.737 & 3.737 & 0 & & & \\
\hline y, ave. depth flow, ft & 5.64 & 6.21 & 4.07 & 5.35 & 5.35 & ERR \\
\hline S1, slope EGL & 0.015 & 0.0127 & 0 & & & \\
\hline $\mathrm{P}$, wetted perimeter, MC, ft & 29 & 29 & 0 & & & \\
\hline R, hydraulic Radius, ft & 5.448 & 6.000 & ERR & & & \\
\hline $\mathrm{V}^{*}$, shear velocity, ft/s & 1.622 & 1.566 & $\mathrm{~N} / \mathrm{A}$ & & & \\
\hline $\mathrm{V} * / \mathrm{w}$ & 0.434 & 0.419 & ERR & & & \\
\hline $\begin{array}{l}\text { Bed transport coeff., } \mathrm{kl},(0.59 \text { if } \\
\mathrm{kl}\end{array}$ & $\begin{array}{l}\mathrm{V} * / \mathrm{w}<0.5 ; \\
0.59\end{array}$ & $\begin{array}{l}0.64 \text { if } \\
0.59\end{array}$ & $\begin{array}{c}.5<\mathrm{V} * / \mathrm{w}<2 \\
0\end{array}$ & ; 0.69 if & $\mathrm{V} * / \mathrm{w}>2.0$ & $0 \mathrm{p} .33)$ \\
\hline $\mathrm{y}^{2}$, depth in contraction, ft & 4.60 & 5.35 & ERR & & & \\
\hline
\end{tabular}

Clear water Contraction Scour in MAIN CHANNEL

$\mathrm{Y} 2=\left(\mathrm{Q} 2^{\wedge} 2 /\left(131 * \mathrm{Dm}^{\wedge}(2 / 3) * \mathrm{~W} 2^{\wedge} 2\right)\right)^{\wedge}(3 / 7) \quad$ Converted to English Units

ys $=$ y $2-y \_$bridge

(Richardson and others, 1995, p. 32, eq. 20, 20a)

Approach Section

Q100 Q500 Qother

Main channel Area, ft2

$158 \quad 174 \quad 114$

Main channel width, ft

y1, main channel depth, ft

$\begin{array}{lll}28 & 28 & 28\end{array}$

$5.64 \quad 6.21 \quad 4.07$

Bridge Section 


\begin{tabular}{|c|c|c|c|}
\hline (Q) total discharge, cfs & 1450 & 2150 & 410 \\
\hline (Q) discharge thru bridge, cfs & 1158 & 1691 & 410 \\
\hline Main channel conveyance & 12250 & 11127 & 2584 \\
\hline Total conveyance & 12250 & 11127 & 2584 \\
\hline Q2, bridge MC discharge, cfs & 1158 & 1691 & 410 \\
\hline Main channel area, ft2 & 189 & 190 & 55 \\
\hline Main channel width (skewed), ft & 35.25 & 35.51 & 27.71 \\
\hline Cum. width of piers in MC, ft & 0.0 & 0.0 & 0.0 \\
\hline w, adjusted width, ft & 35.25 & 35.51 & 27.71 \\
\hline Y_bridge (avg. depth at br.), ft & 5.35 & 5.35 & 1.98 \\
\hline Dm, median $(1.25 * \mathrm{D} 50)$, ft & 0.26075 & 0.26075 & 0.26075 \\
\hline $\mathrm{y}^{2}$, depth in contraction, ft & 3.62 & 4.98 & 1.83 \\
\hline ys, scour depth (y2-ybridge), & 1.73 & -0.37 & -0.15 \\
\hline
\end{tabular}

Pressure Flow Scour (contraction scour for orifice flow conditions)

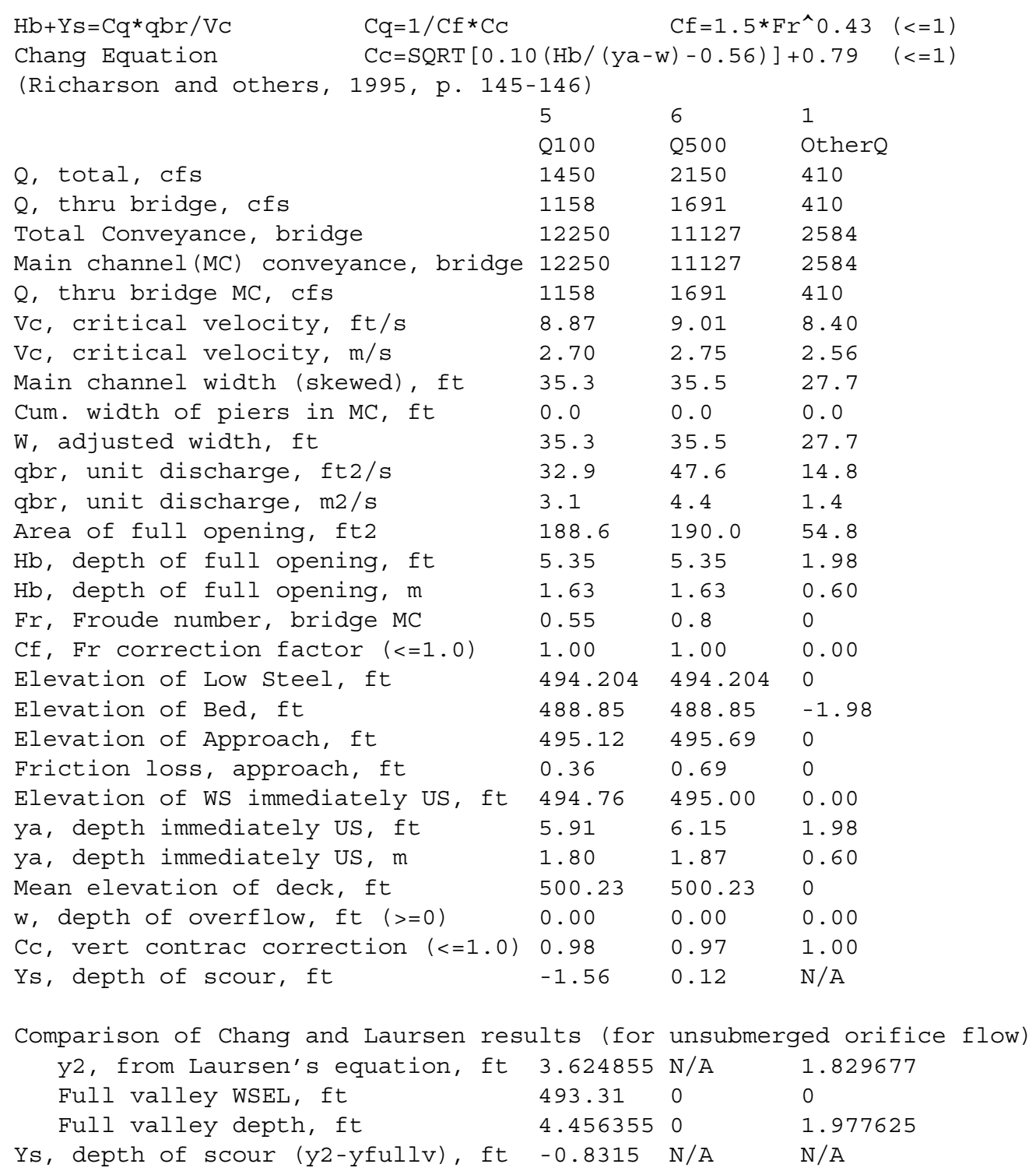




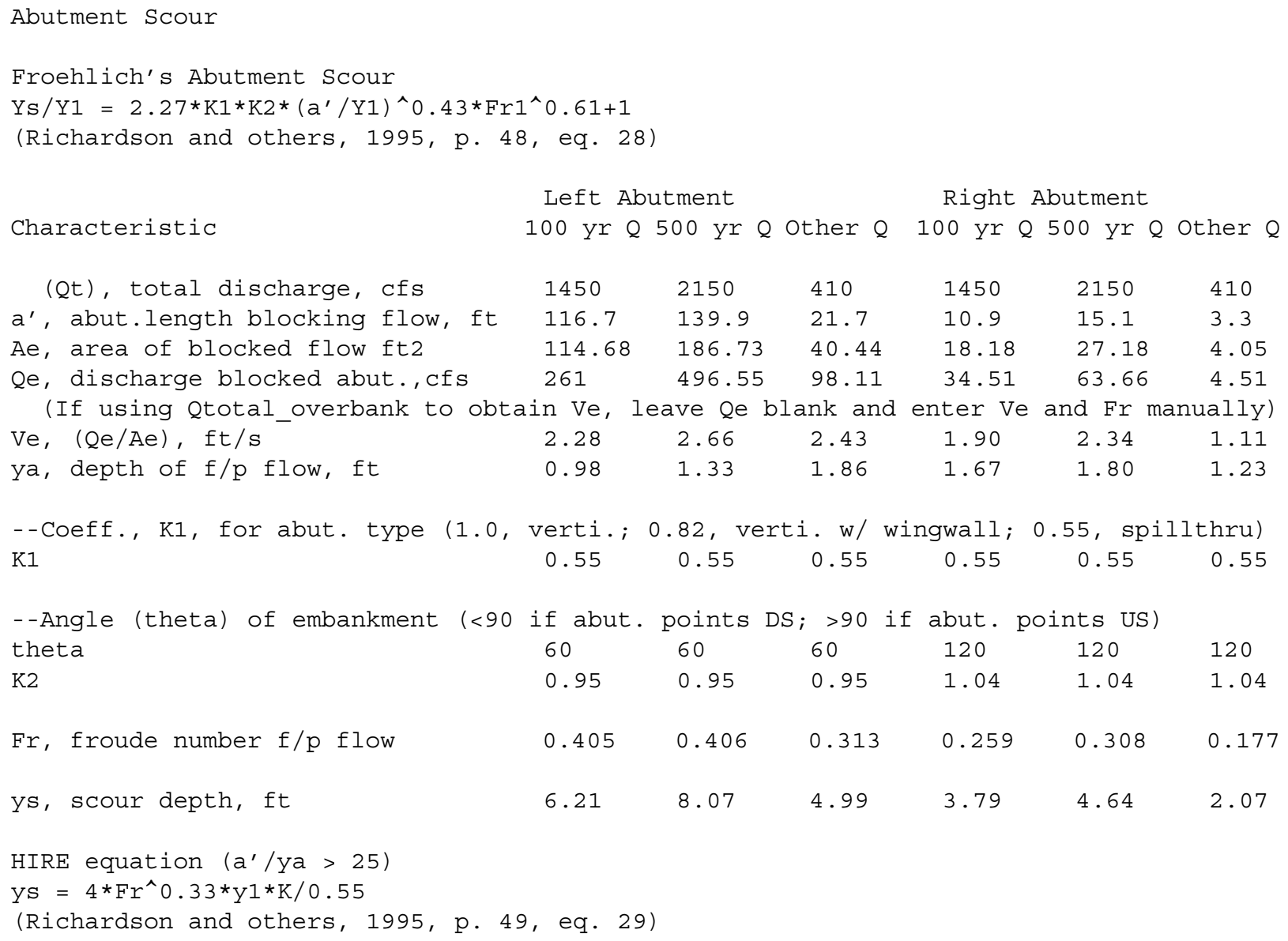




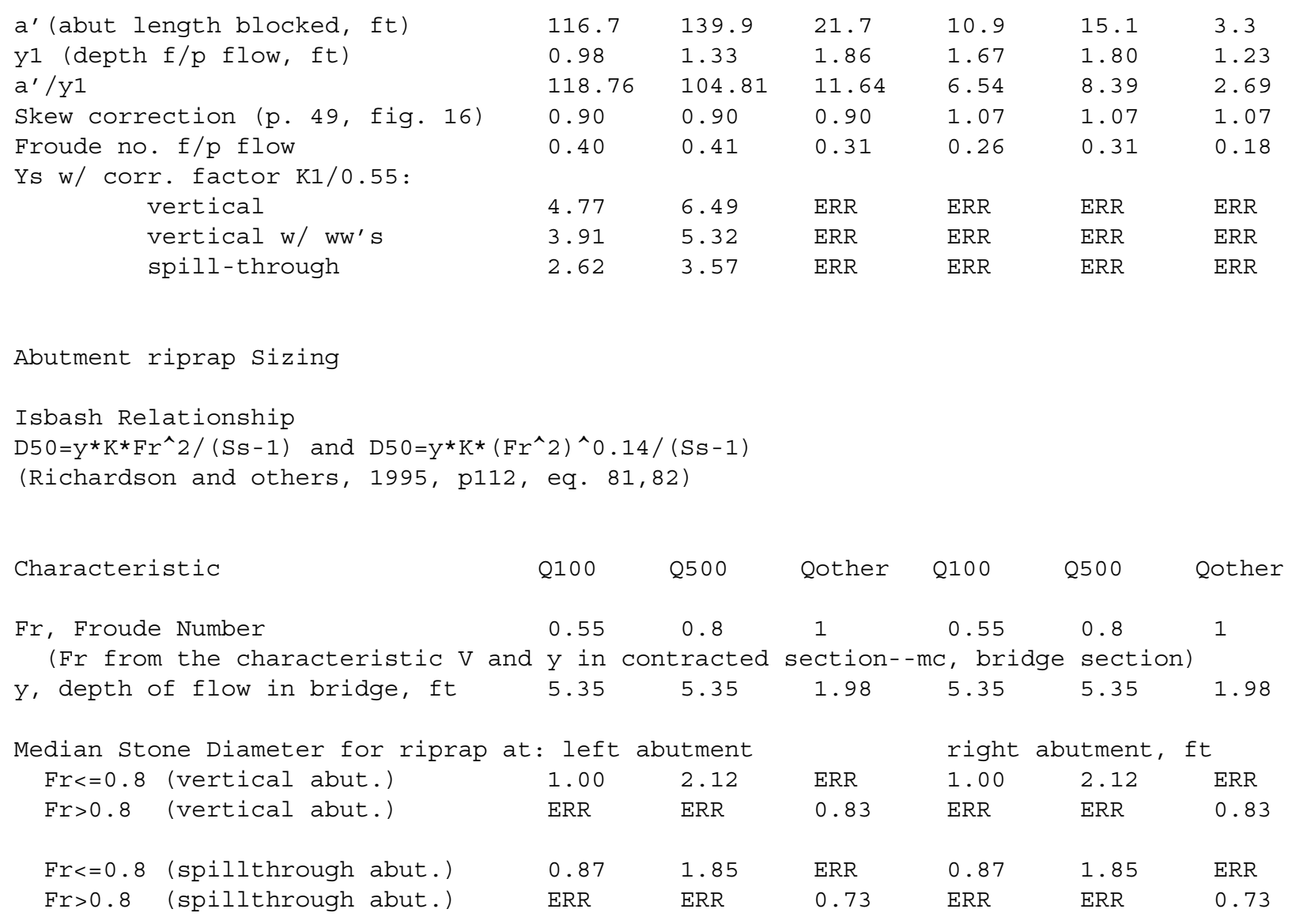


